\title{
Enhanced Hydrogen Storage Properties of Li-RHC System with In-House Synthesized $\mathrm{AlTi}_{3}$ Nanoparticles
}

\author{
Thi-Thu Le ${ }^{1}$, Claudio Pistidda ${ }^{1, *(\mathbb{D})}$, Julián Puszkiel ${ }^{1,2}$, , María Victoria Castro Riglos ${ }^{3}$, \\ David Michael Dreistadt ${ }^{1} \mathbb{1}$, Thomas Klassen ${ }^{1,2} \mathbb{D}$ and Martin Dornheim ${ }^{1, *}$ \\ 1 Institute of Hydrogen Technology, Helmholtz-Zentrum Hereon GmbH, D-21502 Geesthacht, Germany; \\ thi.le@hereon.de (T.-T.L.); julian.puszkiel@hereon.de (J.P.); david.dreistadt@hereon.de (D.M.D.); \\ thomas.klassen@hereon.de (T.K.) \\ 2 Faculty of Mechanical Engineering, Helmut Schmidt University/University of the Federal Armed Forces, \\ 22043 Hamburg, Germany \\ 3 Department of Metalphysics, Consejo Nacional de Investigaciones Científicas y Técnicas (CONICET) and \\ Centro Atómico Bariloche, San Carlos de Bariloche R8402AGP, Argentina; viquiriglos@gmail.com \\ * Correspondence: claudio.pistidda@hereon.de (C.P.); martin.dornheim@hereon.de (M.D.); \\ Tel.: +49-(0)41-5287-2644 (C.P.); +49-(0)41-5287-2604 (M.D.)
}

check for updates

Citation: Le, T.-T.; Pistidda, C.; Puszkiel, J.; Castro Riglos, M.V.; Dreistadt, D.M.; Klassen, T.; Dornheim, M. Enhanced Hydrogen Storage Properties of Li-RHC System with In-House Synthesized $\mathrm{AlTi}_{3}$ Nanoparticles. Energies 2021, 14, 7853. https://doi.org/10.3390/en14237853

Academic Editors: Luca Gonsalvi and Francesco Frusteri

Received: 11 October 2021

Accepted: 17 November 2021

Published: 23 November 2021

Publisher's Note: MDPI stays neutral with regard to jurisdictional claims in published maps and institutional affiliations.

Copyright: (c) 2021 by the authors. Licensee MDPI, Basel, Switzerland. This article is an open access article distributed under the terms and conditions of the Creative Commons Attribution (CC BY) license (https:/ / creativecommons.org/licenses/by/ $4.0 /)$.
Abstract: In recent years, the use of selected additives for improving the kinetic behavior of the system $2 \mathrm{LiH}+\mathrm{MgB}_{2}$ (Li-RHC) has been investigated. As a result, it has been reported that some additives (e.g., $3 \mathrm{TiCl}_{3} \cdot \mathrm{AlCl}_{3}$ ), by reacting with the $\mathrm{Li}-\mathrm{RHC}$ components, form nanostructured phases (e.g., $\mathrm{AlTi}_{3}$ ) possessing peculiar microstructural properties capable of enhancing the system's kinetic behavior. The effect of in-house-produced $\mathrm{AlTi}_{3}$ nanoparticles on the hydrogenation/dehydrogenation kinetics of the $2 \mathrm{LiH}+\mathrm{MgB}_{2}$ (Li-RHC) system is explored in this work, with the aim of reaching high hydrogen storage performance. Experimental results show that the $\mathrm{AlTi}_{3}$ nanoparticles significantly improve the reaction rate of the Li-RHC system, mainly for the dehydrogenation process. The observed improvement is most likely due to the similar structural properties between $\mathrm{AlTi}_{3}$ and $\mathrm{MgB}_{2}$ phases which provide an energetically favored path for the nucleation of $\mathrm{MgB}_{2}$. In comparison with the pristine material, the Li-RHC doped with $\mathrm{AlTi}_{3}$ nanoparticles has about a nine times faster dehydrogenation rate. The results obtained from the kinetic modeling indicate a change in the $\mathrm{Li}-\mathrm{RHC}$ hydrogenation reaction mechanism in the presence of $\mathrm{AlTi}_{3}$ nanoparticles.

Keywords: in-house-synthesized additive; $\mathrm{AlTi}_{3}$ nanoparticles; kinetics; reaction mechanism; reactive hydride composite

\section{Introduction}

Hydrogen plays a crucial role in the transition from a fossil-fuel-based to a renewableenergy-based society. In comparison with other energy carriers such as natural gas $(13.9 \mathrm{kWh} / \mathrm{kg})$ and liquid hydrocarbons $(12.4 \mathrm{kWh} / \mathrm{kg})$, hydrogen has the highest gravimetric energy density per mass $(33.3 \mathrm{kWh} / \mathrm{kg})[1,2]$. As a result, in the context of a net-zero $\mathrm{CO}_{2}$ strategy, using hydrogen as an energy vector to replace environmentally harmful fossil fuels will enable, on the one hand, a drastic reduction in $\mathrm{CO}_{2}$ emissions and, on the other hand, a more efficient and synergic utilization of the intermittent and unevenly distributed renewable energy sources [3,4]. However, at standard conditions $\left(0{ }^{\circ} \mathrm{C}\right.$ and 1 bar $)$, hydrogen has an extremely low volumetric density $\left(0.089 \mathrm{~kg} / \mathrm{m}^{3}\right.$ at room temperature and under 1 bar) [5,6], which results in a low energy per unit volume $\left(0.003 \mathrm{kWh} / \mathrm{dm}^{3}\right)$ when compared with natural gas $\left(0.008 \mathrm{kWh} / \mathrm{dm}^{3}\right)$ and liquid hydrocarbons $\left(10.5 \mathrm{kWh} / \mathrm{dm}^{3}\right)$. In this scenario, the development of advanced storage methods is essential. Hydrogen is conventionally stored in liquid and gaseous form. However, these storage methods face cost and safety issues. For example, compressed gas storage systems need compressors to reach storage pressures of $350-700$ bar. In fact, about $12 \%$ of the low heating volume (LHV) 
is necessary to reach a storage pressure of 350 bar (and 15\% of the LHV for 700 bar) in the actual compression operation [7]. In comparison to hydrogen compression, the energy spent for hydrogen liquefaction is substantially higher (around 30\% of the LHV) due to complex process steps that aim to achieve low temperatures (liquefaction temperature of $\mathrm{H}_{2}:-252.9^{\circ} \mathrm{C}$ ) and to avoid the boiling off effect. Such demanding constraints make these physical storage methods unsuitable, especially for long-term storage applications [8,9]. A potentially plausible storage solution for large quantities of hydrogen is geological storage in suitable geological formations (e.g., underground salt caverns, sub-sea reservoirs) [4]. However, a disadvantage is the localized availability of suitable geological formations.

The adsorption of hydrogen on high-surface-area materials has been studied in recent decades as one of the chemical approaches for storing hydrogen. Several materials, including zeolites, carbon-based compounds, and metal-organic frameworks (MOFs), have been studied. The fundamental disadvantage of this method is that, to absorb substantial amounts of hydrogen, cryogenic temperatures must be applied $[10,11]$. In fact, at room temperature (RT), none of the above-mentioned materials can reach the gravimetric storage capacity given in the targets of the Department of Energy for onboard hydrogen storage in light-duty fuel cell (FC) vehicles [12]. Hydrogen clathrate hydrate structures offer another option to store hydrogen in molecular form. However, this method requires extreme pressures $\left(\sim 3000\right.$ bar at $\left.77^{\circ} \mathrm{C}\right)$ or the employment of foreign molecules such as tetrahydrofuran (THF) $[6,13,14]$. Another chemical method to store hydrogen is in the atomic form in hydrides-based solid-state systems. The advantages of using such a storage approach are the possibility to achieve high volumetric density, low operating pressures, and high safety standards $[9,15,16]$. Metal hydride-based hydrogen storage solutions have been shown at a scale that is appropriate for effective deployment in the context of the energy transition [17-19]. These applications, however, are dependent on the usage of so-called "low-temperature metal hydrides" (i.e., $\mathrm{TiFe} \mathrm{Ti}_{1.1} \mathrm{CrMn}$, etc.) that have a poor gravimetric hydrogen capacity despite having excellent volumetric hydrogen density. Aiming at designing storage systems with high gravimetric capacity, complex metal hydrides and complex metal-hydride-based systems have attracted considerable attention. Among the complex metal hydrides, $\mathrm{LiBH}_{4}$ has been considered a potential candidate for solid-state hydrogen storage due to a theoretical gravimetric capacity of $18.5 \mathrm{wt}$. \% $\mathrm{H}_{2}$ and a volumetric hydrogen storage capacity of $121 \mathrm{~kg} \mathrm{H}_{2} / \mathrm{m}^{3}$ [20-27]. This hydride, however, was initially not considered suitable for reversible hydrogen storage purposes due to the lack of reversibility under moderate temperature and hydrogen pressure [9-14]. At the beginning of the 2000s, by applying an approach similar to the one proposed in 1967 for tuning the thermodynamic properties of the $\mathrm{MgH}_{2}$ [28], it was demonstrated that complex metal hydrides such as $\mathrm{LiBH}_{4}$ could be used in combination with other hydrides to store hydrogen under moderate temperature and hydrogen pressure conditions reversibly. These systems are the so-called reactive hydride composites (RHCs) [29-31]. These composites consist of the combination of two or more hydrides to form new compounds that might reduce the overall reaction enthalpy of the system and encourage its reversibility while still maintaining the hydrogen storage capacity of the original materials. Examples of such hydride mixtures are $2 \mathrm{LiBH}_{4}+\mathrm{MgH}_{2}[30,31], 2 \mathrm{NaBH}_{4}+\mathrm{MgH}_{2}[32,33]$, $2 \mathrm{Mg}\left(\mathrm{NH}_{2}\right)_{2}+4 \mathrm{LiH}[34,35]$, or $6 \mathrm{Mg}\left(\mathrm{NH}_{2}\right)_{2}+9 \mathrm{LiH}+\mathrm{LiBH}_{4}$ [36]. However, RHCs often exhibit poor kinetic behaviors; thus, the dehydrogenation/hydrogen processes occur at temperatures higher than thermodynamically expected. The kinetic constraints are likely to be caused by the involvement of the system components in complex reaction steps taking place at their interfaces. In addition, the hydrogen desorption from a complex hydride such as a borohydride and amides requires high energy to break the strong bonds of anionic complexes (i.e., $\left(\mathrm{BH}_{4}\right)^{-}$and $\left(\mathrm{NH}_{2}\right)^{-}$), to recombine the $\mathrm{H}$ atoms to form $\mathrm{H}_{2}$ molecules and to promote the long-range diffusion of the reacting species.

Microstructure modifications via mechanical processes (ball milling [37-41], cold rolling [42], high-pressure torsion (HPT) [43], or equal channel angular pressing [44]) can improve the sorption properties of hydride materials. Nevertheless, this enhancement is 
only temporary due to the unavoidable growth and agglomeration phenomena occurring during dehydrogenation-rehydrogenation cycling. Long-lasting improvements of the kinetic properties of complex hydrides and RHCs can be achieved by using transition metals (TM)-based additives [36,45-54]. Several investigations on the effect of the addition of TMbased additives on the kinetic properties of the RHCs have been conducted [45,46,50,55-61]. In most cases, the added components reacted with the hydride system during milling, forming more stable TM compounds. These new compounds have a typical particle size in the nanometric range between 5-20 nm [45,46,50,57,60-62].

From metallurgical studies, it is well known that structural similarities between a newly forming phase and its parental phase, lower the interface energy due to the reduced interatomic and interface lattice misfit. In particular, the nucleation of a new phase on a parental one is promoted when their structural properties meet the so-called "Edge-to-Edge model's criteria" [63], i.e., interatomic spacing of their most close-packed atom rows and their interplanar mismatch are lower than $10 \%$ and $6 \%$, respectively.

For the $2 \mathrm{LiH}+\mathrm{MgB}_{2}$ (or $\left.2 \mathrm{LiBH}_{4}+\mathrm{MgH}_{2}\right)$ system, it is known that the addition of selected additives leads to the improvement of hydrogenation-dehydrogenation properties via the formation of nano-dispersed TM compounds that act as energetically favored nucleation centers for the formation of $\mathrm{MgB}_{2}$. In our previous work [50], we found that, in the $2 \mathrm{LiH}+2 \mathrm{MgB}_{2}$ system ( $\mathrm{Li}-\mathrm{RHC}$ ), the nano-sized hexagonal- $\mathrm{AlTi}_{3}$ particles formed in situ during high energy ball milling of $3 \mathrm{TiCl}_{3} \cdot \mathrm{AlCl}_{3}$. The in situ formation of nanosized hexagonal- $\mathrm{AlTi}_{3}$ particles notably enhanced the kinetic dehydrogenation behavior of the Li-RHC composite by promoting the formation of a hexagonal- $\mathrm{MgB}_{2}$ nucleus onto nano-sized hexagonal- $\mathrm{AlTi}_{3}$ particles. Motivated by these outstanding results and aimed at minimizing the reduction of hydrogen storage capacity due to the additive-RHC side reactions, which usually lead to the formation of stable species, e.g., containing $\mathrm{Cl}^{-}$, inhouse-synthesized $\mathrm{AlTi}_{3}$ nanoparticles were used as a dopant in the Li-RHC system. In particular, the effect of adding the hexagonal $\mathrm{AlTi}_{3}$ nanoparticles (hexa-AlTi 3 ) on the hydrogenation-dehydrogenation kinetic properties of $2 \mathrm{LiH}+\mathrm{MgB}_{2}$ was investigated. The obtained results are presented and discussed below.

\section{Materials and Methods}

Material preparation: lithium hydride ( $\mathrm{LiH}, 95 \%$ purity, Sigma Aldrich, St. Louis, MO, USA), magnesium boride ( $\mathrm{MgB}_{2}, 99 \%$ purity, Alfa Aesar, Haverhill, MA, USA), aluminum (III) chloride-titanium (III) chloride $\left(3 \mathrm{TiCl}_{3} \cdot \mathrm{AlCl}_{3}, \sim 76-78 \% \mathrm{TiCl}_{3}\right.$ purity, Fisher Scientific, Waltham, MA, USA) and sodium hydride (NaH, 90\% purity, Sigma-Aldrich) were purchased from commercial suppliers without further treatments. One of the most common methods for synthesizing of the Al-Ti system is ball milling [64], thus in this study, $\mathrm{AlTi}_{3}$ nanoparticles were also synthesized via the mechanochemical driven reaction between $\mathrm{NaH}$ and $3 \mathrm{TiCl}_{3} \cdot \mathrm{AlCl}_{3}$ in the molar ratio of $12: 1$. The reaction is expected to proceed as follows:

$$
12 \mathrm{NaH}(\mathrm{s})+\left(3 \mathrm{TiCl}_{3} \cdot \mathrm{AlCl}_{3}\right)(\mathrm{s}) \rightarrow 12 \mathrm{NaCl}(\mathrm{s})+\mathrm{AlTi}_{3}(\mathrm{~s})+\mathrm{H}_{2}(\mathrm{~g})
$$

Two grams of a $\mathrm{NaH}-3 \mathrm{TiCl}_{3} \cdot \mathrm{AlCl}_{3}$ mixture were milled for $180 \mathrm{~min}$ in an argon atmosphere using a hardened stainless steel vial and milling balls (ball to powder (BTP) ratio of 20:1) in an 8000M Mixer/Mill High-Energy Ball Mill. After milling, the obtained powder was first washed with distilled water, and then the solid residues were separated from the liquid fraction via filtration. Washing and filtering were carried out under atmospheric conditions. The washing process might have led to the formation of some oxides. Applying Gibbs minimization equilibrium calculations, the most favorable reaction for the $\mathrm{AlTi}_{3(\mathrm{~s})}$ and $\mathrm{H}_{2} \mathrm{O}_{(\mathrm{l})}$ interaction at $25{ }^{\circ} \mathrm{C}$ and $1 \mathrm{~atm}$ was identified and the Gibbs free energy was calculated as a function of the temperature using the HSC Chemistry software [65]. The species considered for the calculation were: $\mathrm{AlTi}_{3(\mathrm{~s})}, \mathrm{H}_{2} \mathrm{O}_{(\mathrm{l})}, \mathrm{H}_{2(\mathrm{~g})}$, $\mathrm{Al}_{2} \mathrm{O}_{3(\mathrm{~s})}, \mathrm{TiH}_{2(\mathrm{~s})}, \mathrm{Al}_{(\mathrm{s})}, \mathrm{TiO}_{(\mathrm{s})}, \mathrm{TiO}_{2(\mathrm{~s})}, \mathrm{Ti}_{2} \mathrm{O}_{3(\mathrm{~s})}, \mathrm{O}_{2(\mathrm{~g})}$, and $\mathrm{AlTi}_{(\mathrm{s})}$. The thermodynamic data of the $\mathrm{AlTi}_{3}$ added to the database of the software were referred to [66]. The solid 
residues were dried in a glass oven under a dynamic vacuum $\left(\sim 10^{-2}\right.$ bar $)$ at $100{ }^{\circ} \mathrm{C}$ for $12 \mathrm{~h}$ and then characterized by X-ray diffraction (XRD), high-resolution transmission electron microscopy (HR-TEM).

The steps followed for preparing the system Li-RHC and the Li-RHC doped with the prepared $\mathrm{AlTi}_{3}$ nanoparticles (denoted as $\mathrm{Li}-\mathrm{RHC}+\mathrm{AlTi}_{3}$ ) are identical to those followed for the preparation of the system Li-RHC doped with $3 \mathrm{TiCl}_{3} \cdot \mathrm{AlCl}_{3}$ described in [50]. The amount of added $\mathrm{AlTi}_{3}$ was calculated to be equal to the amount of $\mathrm{Al}-\mathrm{Ti}$ contained in the Li-RHC doped with $7.5\left(3 \mathrm{TiCl}_{3} \cdot \mathrm{AlCl}_{3}\right)$, that is, about $1.7 \mathrm{wt}$. \% of $\mathrm{AlTi}_{3}$ was added to the Li-RHC system. All materials were handled and prepared in MBraun Unilab glove boxes under a continuously purified air flow $\left(\mathrm{O}_{2}\right.$ and $\mathrm{H}_{2} \mathrm{O}$ levels $\left.<2 \mathrm{ppm}\right)$.

$X$-ray diffraction (XRD): the XRD characterization of the investigated specimens was carried out using a Bruker D8 Discover device. This diffractometer is equipped with a copper X-ray source ( $\mathrm{Cu} \mathrm{K} \alpha$ radiation, $\lambda=1.54184 \AA$ ) and a VANTEC general area detector from Bruker. The diffraction patterns were acquired in nine steps in the $2 \theta$ range from $10^{\circ}$ to $90^{\circ}$ with an exposure time of $300 \mathrm{~s}$ per step. The preparation of the specimens to be analyzed via XRD was carried out in an MBraun Unilab glove box under a continuously purified argon flow $\left(\mathrm{O}_{2}\right.$ and $\mathrm{H}_{2} \mathrm{O}$ levels $\left.<2 \mathrm{ppm}\right)$. For this purpose, a small amount of powder $(\approx 5 \mathrm{mg})$ was placed onto a sample holder and sealed with an airtight transparent dome made of poly-methyl-methacrylate (PMMA) to avoid oxidation or hydrolysis phenomena during the pattern acquisition. For all the XRD patterns, the bump between $10^{\circ}$ and $\sim 25^{\circ}$ comes from the PMMA dome.

Volumetric analysis: the dehydrogenation-hydrogenation behavior of the studied material was investigated using a Sieverts type apparatus designed by Hydro-Quebec/HERA Hydrogen Storage Systems Inc. (Longueuil, QC, Canada) or in a similar home-built volumetric device. Both machines operate in the same manner, in which a differential pressure gauge connects the sample volume and a reference volume, and thus all temperatureinduced pressure changes are compensated and only differences due to sorption processes are recorded. By considering the exact sample mass, typically around $160 \mathrm{mg}$, the pressure changes are converted into changes of the gravimetric hydrogen content of the investigated samples, i.e., the results are given in the unit "wt. \% $\mathrm{H}_{2}$ ". If not otherwise described in the text, the dehydrogenation-hydrogenation cycles of each sample were measured at a hydrogen pressure of $3 \mathrm{bar}$ and $400^{\circ} \mathrm{C}$ for the dehydrogenation and a hydrogen pressure of 50 bar and $350{ }^{\circ} \mathrm{C}$ for the hydrogenation. The chosen pressure and temperature conditions are based on the published thermodynamic data and previous studies for the Li-RHC system $[30,31,67]$. The dehydrogenation-hydrogenation measurements were carried out until the measured values reached a plateau region that met the criteria: $\Delta w \mathrm{t} . \%=0.0002$ and $\Delta \mathrm{t}(\mathrm{min})=1$. To determine the activation energy, several experiments performed on the $\mathrm{Li}-\mathrm{RHC}+\mathrm{AlTi}_{3}$ material were carried out in the range of temperature between $370{ }^{\circ} \mathrm{C}$ and $400{ }^{\circ} \mathrm{C}$ under 50 bar for hydrogenation and under 3 bar for dehydrogenation. These kinetic curves were fitted with a selected reaction model [68-71], and a kinetic constant rate $(k)$ is acquired for each kinetic curve fitted. Then, the activation energy of the Li-RHC $+\mathrm{AlTi}_{3}$ sample can be obtained using the Arrhenius equation:

$$
k=A * e^{\frac{-E_{a}}{R T}} \text { or } \ln k=-\frac{E_{a}}{R T}+\ln A
$$

Plotting $\ln k$ versus the inverse of temperature $1 / \mathrm{T}(\mathrm{T}=$ temperature $)$ yields a straight line with a slope of $-\frac{E_{a}}{R}$ that allows calculating the activation energy $E_{\mathrm{a}}$.

High-resolution transmission electron microscopy (HR-TEM): HR-TEM images were obtained using high-resolution transmission electron microscopy (HR-TEM). Observations were completed with a Tecnai F30 microscope (FEI Company, Hillsboro, OR, USA) with an information limit of $0.12 \mathrm{~nm}$ and Schottky field emission gun operating at $300 \mathrm{kV}$. The samples were exposed to air for a very short time. HR-TEM image processing was conducted with the following programs: Digital Micrograph (License $n^{\circ}$. 90294175), i-TEM (License $\mathrm{n}^{\mathrm{O}}$. A2382500), and JEMs (License $\mathrm{n}^{\mathrm{O}}$. IEb59yBDflUMh). 


\section{Results and Discussion}

Figure 1 shows the XRD patterns of the in-house-prepared $\mathrm{AlTi}_{3}$ nanoparticles and $\mathrm{Li}$ RHC-doped $\mathrm{AlTi}_{3}$. The XRD pattern of the mixture of $\mathrm{NaH}$ and $3 \mathrm{TiCl}_{3} \cdot \mathrm{AlCl}_{3}$ after milling reported in Figure 1a mainly exhibits the presence of $\mathrm{NaCl}(\eta)$. Paying particular attention to the pattern background, in the $2 \theta$ range between $30^{\circ}$ and $40^{\circ}$, it is possible to notice the presence of low-intensity reflections ascribed to $\mathrm{AlTi}_{3}(\pi)$. The XRD pattern acquired for the material after washing and drying does not show the presence of the $\mathrm{NaCl}$ (Figure $1 \mathrm{~b}$ ). However, the broad diffraction peaks of hexagonal $\mathrm{AlTi}_{3}$ are visible at $2 \theta=35.7^{\circ}, 38.9^{\circ}$, and $40.6^{\circ}$. This result indicates that $\mathrm{NaCl}$ was completely removed during the washing process. Moreover, the interaction with water might result in the formation of some oxides. In this regard, composition phase equilibrium calculations were performed to consider the possible formation of oxide species (Supplementary Materials ESI-Figure S1). Taking into account excess water, the most thermodynamically favorable reaction would lead to the

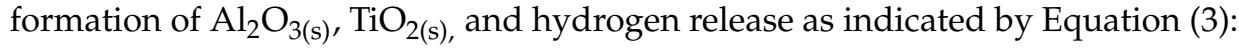

$$
2 \mathrm{AlTi}_{3(\mathrm{~s})}+15 \mathrm{H}_{2} \mathrm{O}_{(\mathrm{l})} \leftrightarrows \mathrm{Al}_{2} \mathrm{O}_{3(\mathrm{~s})}+6 \mathrm{TiO}_{2(\mathrm{~s})}+15 \mathrm{H}_{2(\mathrm{~g})}, \Delta \mathrm{G}^{0}=-3488.7 \mathrm{~kJ} / \mathrm{mol}
$$

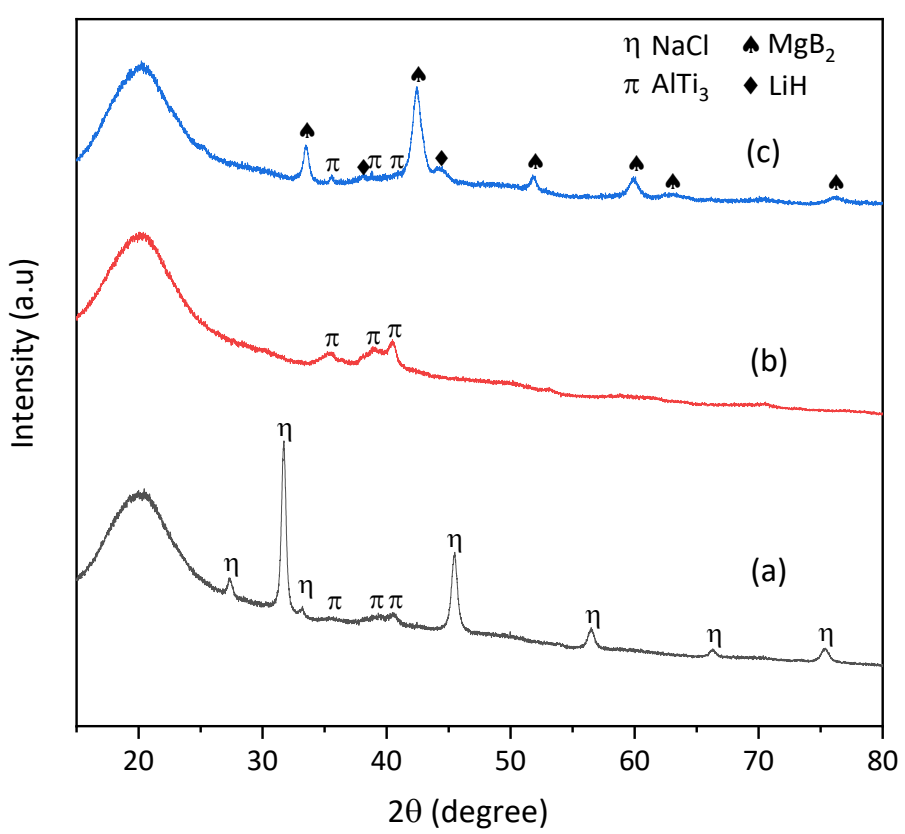

Figure 1. $\mathrm{XRD}$ patterns of the composites: (a) mixture of $\mathrm{NaH}+3 \mathrm{TiCl}_{3} \cdot \mathrm{AlCl}_{3}$ after milling; (b) mixture of $\mathrm{NaH}+3 \mathrm{TiCl}_{3} \cdot \mathrm{AlCl}_{3}$ after washing and drying; and (c) the $\mathrm{Li}-\mathrm{RHC}+\mathrm{AlTi}_{3}$ sample after milling.

None of the oxide species are seen in the XRD (Figure 1b) and this fact could be ascribed to their low amount or/and their nanometric nature. For the $\mathrm{Li}-\mathrm{RHC}+\mathrm{AlTi}_{3}$ sample after milling (Figure 1c), the XRD diffraction patterns show the presence of the starting phases (e.g., $\mathrm{LiH}, \mathrm{MgB}_{2}$, and $\mathrm{AlTi}_{3}$ ), indicating the $\mathrm{AlTi}_{3}$ nanoparticles do not react with the other reactants during milling.

The existence of hexagonal $\mathrm{AlTi}_{3}$ nanoparticles as well as possible oxide species in the washed material was verified by employing the HR-TEM technique. Supplementary Materials ESI-Figure S2 shows the TEM diffraction patterns and possible phases in the sample $\mathrm{NaH}+3 \mathrm{TiCl}_{3} \cdot \mathrm{AlCl}_{3}$ after washing and drying. As shown there, besides the hexagonal $\mathrm{AlTi}_{3}$ phase (observed via XRD technique), other phases such as $\mathrm{Al}_{3} \mathrm{Ti}$ (tetragonal/hexagonal), $\mathrm{AlTi}_{2}$ (cubic), $\mathrm{AlTi}_{3}$ (cubic), AlTi (tetragonal), and $\mathrm{Al}_{2} \mathrm{O}_{3}$ might be present as well. Further details of the TEM characterization are presented in Figures 2 and 3 HR-TEM micrographs and their respective fast Fourier transform (FFT). Simulated diffraction patterns (DP) in the zone axis condition (ZA) for each possible phase were calculated and compared until the best match was found, thus determining to which phase the particles belonged. This type 
of analysis was performed on several particles. HR-TEM observations combined with the corresponding FFT + simulated DP analysis were performed on several particles. In zone A (Figure 2c) and zone B (Figure 2d), it is possible to observe the presence of hexagonal $\mathrm{AlTi}_{3}$ particles of approximately $10 \mathrm{~nm}$. In addition to the $\mathrm{AlTi}_{3}$ hexagonal nanoparticles, $\mathrm{Al}_{2} \mathrm{O}_{3}$ particles were also found in the washed/dried mixture, as observed by HR-TEM (Figure 3). The formation of $\mathrm{Al}_{2} \mathrm{O}_{3}$ can be attributed to the partial oxidation of the Al-Ti particles during the washing in distilled water, though the presence of titanium oxides was not verified by HR-TEM.

(a) Original width $=46.57 \mathrm{~nm}$

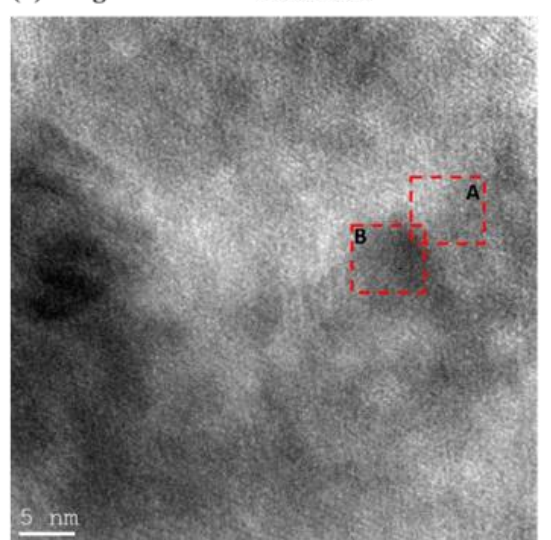

(c). FFT + Simul. DP + $\mathrm{AITi}_{3}$ particle in Zone A
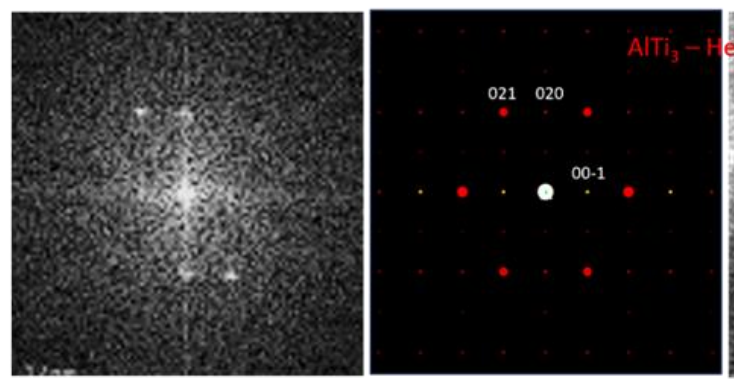

(d). FFT + Simul. DP + $\mathrm{AITi}_{3}$ particle in Zone B
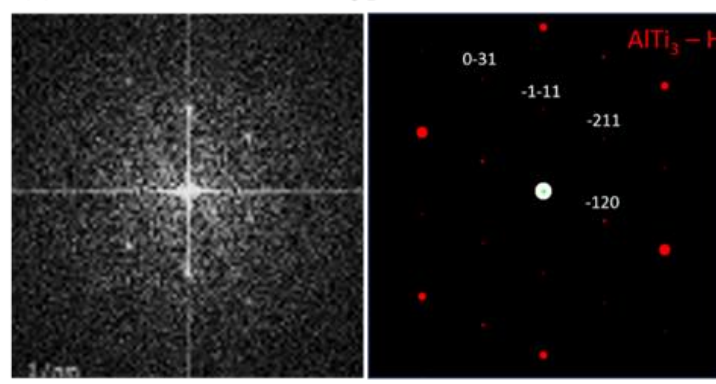

FFT
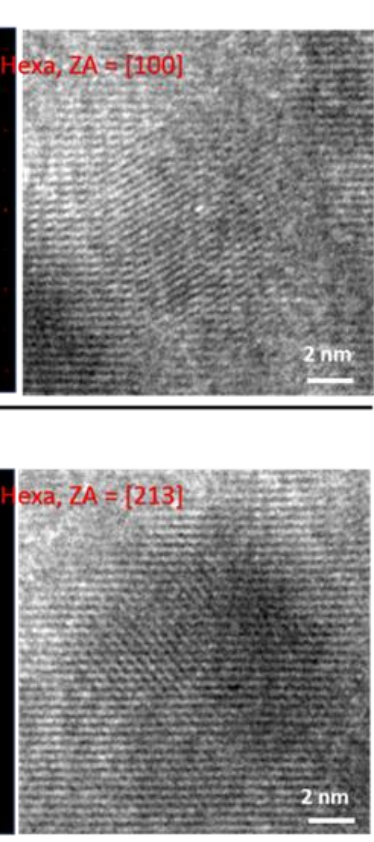

(b) Crop: $1 / 4$ of the original width

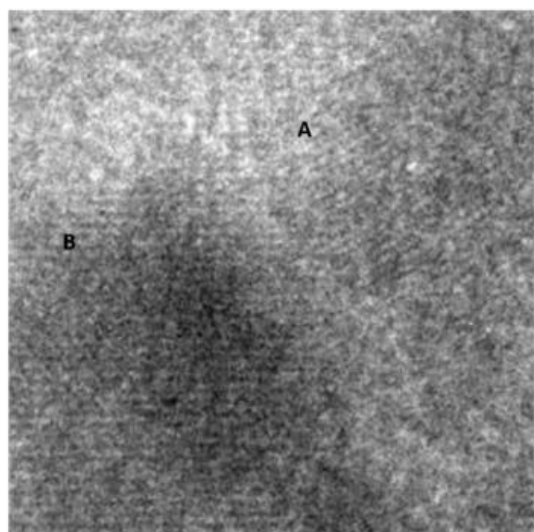

$\mathrm{AlTi}_{3}$ particle

Figure 2. HR-TEM characterization of $\mathrm{AlTi}_{3}$ nanoparticles in $\mathrm{NaH}+3 \mathrm{TiCl}_{3} \cdot \mathrm{AlCl}_{3}$ material after washing: (a) Bright field TEM image captured with original width; (b) Bright field TEM image cropped $\frac{1}{4}$ of the original width; (c) FFT + simul. DP + particle in zone A; and (d) FFT + simul. $\mathrm{DP}+$ particle in zone B. FFT was calculated in each region and compared with simulated diffraction patterns (DPs) in the adequate orientation; the width of the FFT and corresponding simulations are $18 \mathrm{~nm}^{-1}$. 
(a). Original width $=37.62 \mathrm{~nm}$

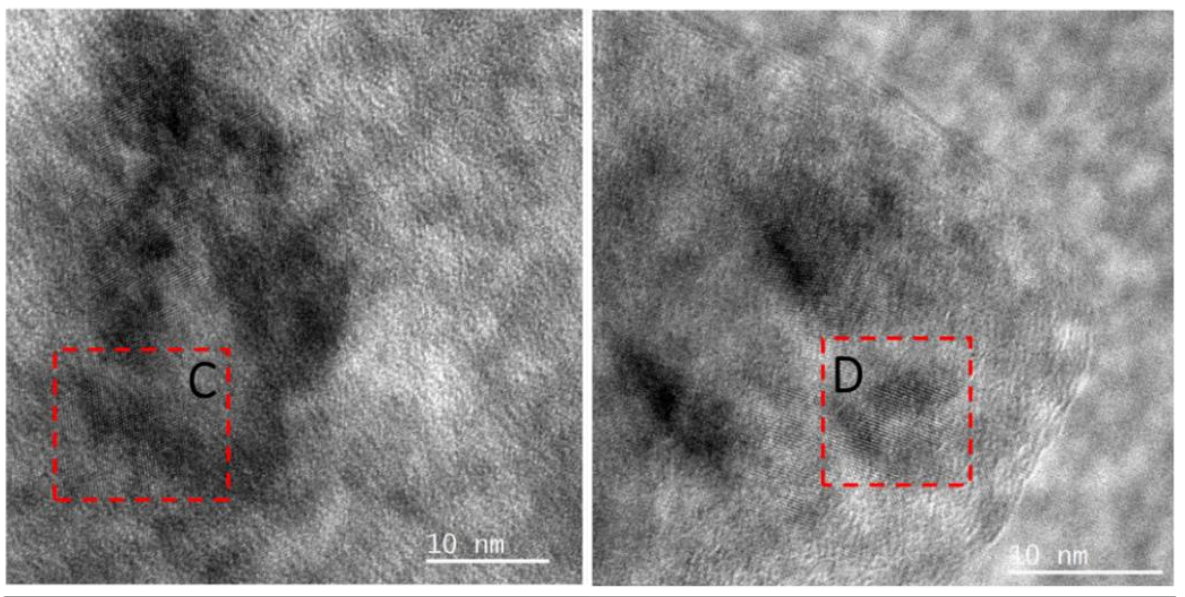

(b). $\mathrm{FFT}+$ Simul. $\mathrm{DP}+\mathrm{Al}_{2} \mathrm{O}_{3}$ particle in Zone $\mathrm{C}$

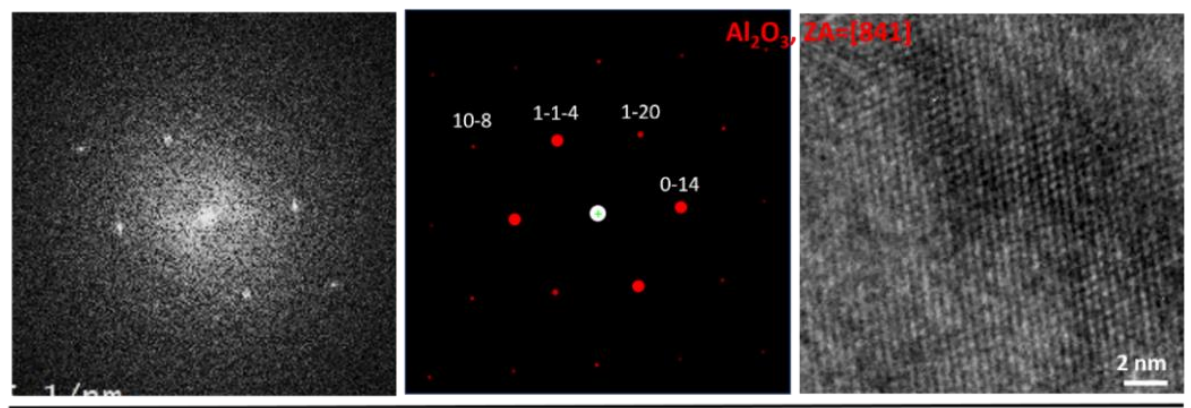

(c). $\mathrm{FFT}+$ Simul. DP $+\mathrm{Al}_{2} \mathrm{O}_{3}$ particle in Zone D
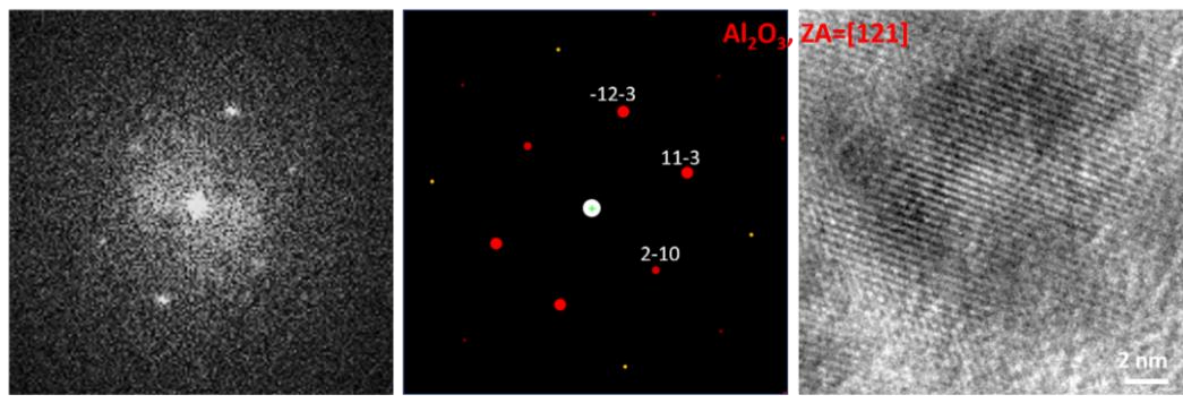

FFT

Simulated DP

$\mathrm{AlTi}_{3}$ particle

Figure 3. HR-TEM characterization of $\mathrm{Al}_{2} \mathrm{O}_{3}$ nanoparticles in $\mathrm{NaH}+3 \mathrm{TiCl}_{3} \cdot \mathrm{AlCl}_{3}$ material after washing: (a) Bright field TEM image captured with original width; (b) FFT + simul. DP + particle in zone C; and (c) FFT + simul. DP + particle in zone D. FFT was calculated in each region and compared with simulated diffraction patterns (DPs) in the adequate orientation; the width of the FFT and corresponding simulations are $18 \mathrm{~nm}^{-1}$.

The effect of the addition of the $\mathrm{AlTi}_{3}$ nanoparticles on the dynamic hydrogen uptake and release properties of the Li-RHC system were examined via the volumetric technique. For comparison, the hydrogenation of the pristine Li-RHC sample is also shown. Figure 4 shows the first hydrogenation both of the pristine Li-RHC and the doped Li-RHC samples. As seen in Figure 4, the hydrogenation kinetic behavior of the Li-RHC material is improved with the presence of additive (i.e., $\mathrm{AlTi}_{3}$ nanoparticles), compared with the pristine Li-RHC material. More specifically, for the pristine material seen in Figure 4B, the hydrogenation starts at approximately $230{ }^{\circ} \mathrm{C}$ and reaches an amount of hydrogen absorbed of roughly $2.4 \mathrm{wt}$. \% at $350{ }^{\circ} \mathrm{C}$. After $25 \mathrm{~h}$ of isothermal treatment at $350{ }^{\circ} \mathrm{C}$, the hydrogen uptake reaches almost $10 \mathrm{wt}$. \% (Figure $4 \mathrm{~A}$ ). This value is slightly lower than the theoretical 
hydrogen capacity found for this system (theoretical hydrogen storage capacity of LiRHC: 11.45 wt. \% $\mathrm{H}_{2}$ ) [31]. The hydrogenation reaction of the doped materials, i.e., $\mathrm{Li}-\mathrm{RHC}+\mathrm{AlTi}_{3}$ starts at about $260^{\circ} \mathrm{C}$ (Figure 4B). The amount of hydrogen stored in the doped materials during the heating to $350^{\circ} \mathrm{C}$ is higher than that of the pristine sample. For Li-RHC + $\mathrm{AlTi}_{3}, 3.7$ wt. $\% \mathrm{H}_{2}$ was stored. Eventually, a total amount of hydrogen uptake of approx. $9.6 \mathrm{wt}$. \% after $20 \mathrm{~h}$ of isothermal treatment at $350{ }^{\circ} \mathrm{C}$ is achieved for $\mathrm{Li}-\mathrm{RHC}+\mathrm{AlTi}_{3}$, respectively (Figure $4 \mathrm{~A}$ ). As observed, the hydrogen storage capacities obtained experimentally are lower than the theoretical value. This is most likely due to the addition of $\mathrm{AlTi}_{3}$ weight. Another possible reason for the loss in hydrogen storage capacity is attributed to the non-homogeneous dispersion of the additive over the host material (Li-RHC), as reported previously [50]. Particularly the hydrogenation kinetics of the $\mathrm{Li}-\mathrm{RHC}+\mathrm{AlTi}_{3}$ is faster during the heating and the beginning of the isothermal period at $350{ }^{\circ} \mathrm{C}$, compared with the neat Li-RHC, suggesting that the presence of $\mathrm{AlTi}_{3}$ nanoparticles improves the hydrogenation rate of the material. The fact that the onset temperature of hydrogenation of the $\mathrm{Li}-\mathrm{RHC}+\mathrm{AlTi}_{3}$ is higher than that of the pristine Li-RHC sample might be related to the experimental fluctuations during the acquisition of the initial points of the measurement.

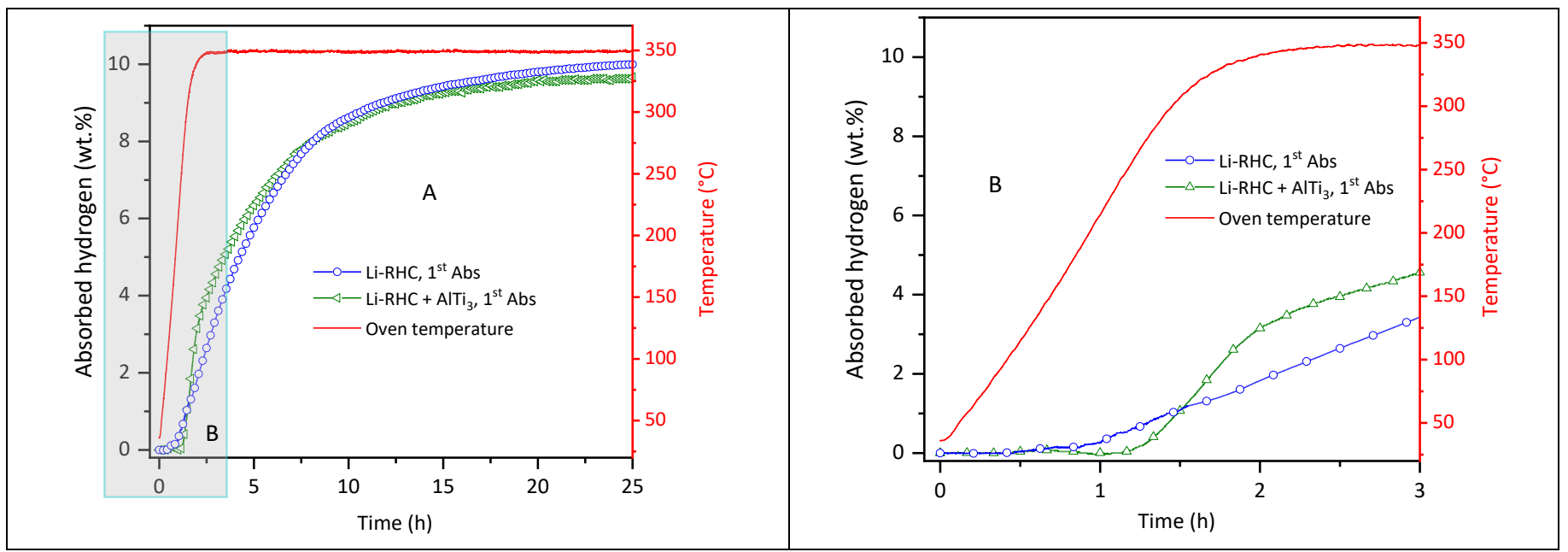

Figure 4. (A) The first hydrogenation reaction of the Li-RHC composites with and without additive, measured from RT to $350{ }^{\circ} \mathrm{C}$, under 50 bar of hydrogen pressure, and (B) magnification of first few hours of hydrogenation of all investigated samples presented in $(\mathbf{A})$.

Similar to hydrogenation, the dehydrogenation kinetic behavior was also analyzed. Figure 5 presents the dehydrogenation properties of the $\mathrm{Li}-\mathrm{RHC}+\mathrm{AlTi}_{3}$ sample over four cycles compared with the undoped Li-RHC sample. The dehydrogenation of the first reaction step, which relates to the decomposition of $\mathrm{MgH}_{2}$, are almost the same for all samples and a corresponding amount of hydrogen release is about $2.2 \mathrm{wt}$. \%. However, for the second dehydrogenation step, the dehydrogenation kinetic behavior of the LiRHC composite is significantly improved and the dehydrogenation is more stable by the presence of the dopant (i.e., $\mathrm{AlTi}_{3}$ ). The dehydrogenation kinetics of the $\mathrm{Li}-\mathrm{RHC}+\mathrm{AlTi}_{3}$ sample (Figure $5 b$ ), for the investigated cycles, are faster than those of the pristine Li-RHC sample (Figure 5a). More specifically, the first dehydrogenation of the Li-RHC $+\mathrm{AlTi}_{3}$ sample requires $\sim 1 \mathrm{~h}$, whereas almost $9 \mathrm{~h}$ are necessary for the neat Li-RHC sample. The following dehydrogenation cycles of the $\mathrm{Li}-\mathrm{RHC}+\mathrm{AlTi}_{3}$ sample are faster than the first dehydrogenation and those of the Li-RHC sample. Furthermore, the stability upon the successive hydrogenation-dehydrogenation cycles also improves markedly for the added $\mathrm{AlTi}_{3}$ material (Figure 5b). 


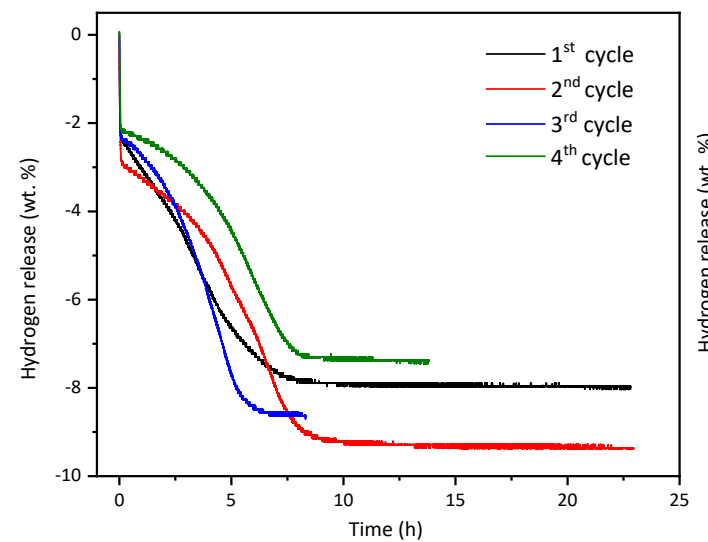

(a)

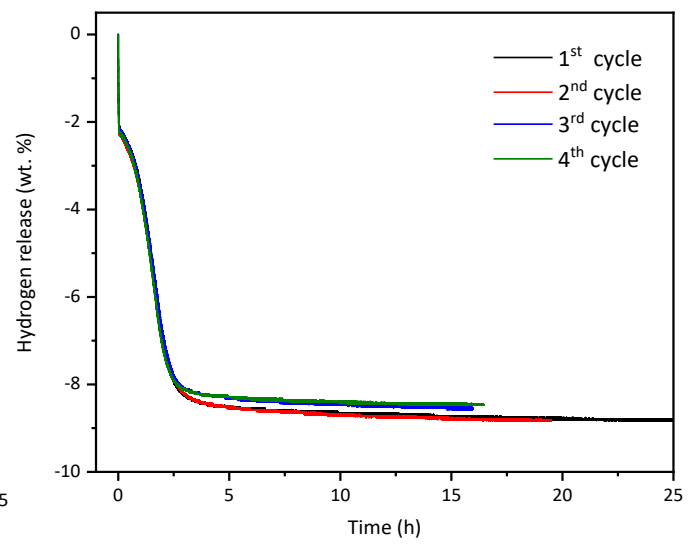

(b)

Figure 5. Dehydrogenation of the pristine $\mathrm{Li}-\mathrm{RHC}(\mathbf{a})$ and $\mathrm{Li}-\mathrm{RHC}+\mathrm{AlTi}_{3}(\mathbf{b})$.

Compared with the pristine material Li-RHC, the addition of $\mathrm{AlTi}_{3}$ nanoparticles significantly improves the hydrogenation-dehydrogenation kinetics of the Li-RHC. However, compared with the material-doped $3 \mathrm{TiCl}_{3} \cdot \mathrm{AlCl}_{3}$ [50], the kinetic performance of $\mathrm{Li}-\mathrm{RHC}+\mathrm{AlTi}_{3}$ leads to similar capacities and slightly slower rates. In this regard, the effective amount of $\mathrm{AlTi}_{3}$ added to the $\mathrm{Li}$-RHC accounts for the observed kinetic performance of the $\mathrm{Li}-\mathrm{RHC}+\mathrm{AlTi}_{3}$. In this study, the powder obtained after washing and drying contains a mixture of $\mathrm{AlTi}_{3}$ and $\mathrm{Al}_{2} \mathrm{O}_{3}$ that appears to be the predominant phases (Figures 2 and 3). Therefore, the used additives are not composed of $100 \%$ of $\mathrm{AlTi}_{3}$. The presence of $\mathrm{Al}_{2} \mathrm{O}_{3}$ might lead to a reduced number of additional nucleation sites (i.e., $\mathrm{AlTi}_{3}$ ) for the formation of $\mathrm{MgB}_{2}$, resulting in a slower hydrogen kinetic behavior of the $\mathrm{Li}-\mathrm{RHC}+\mathrm{AlTi}_{3}$ sample compared with the already reported $\mathrm{Li}-\mathrm{RHC}+3 \mathrm{TiCl}_{3} \cdot \mathrm{AlCl}_{3}$ sample [39].

In the case of these kinds of materials, the crystallographic similarity between the newly forming phase and its parental phase can be evaluated by their interfacial energy. A minimized interfacial energy prompts a proper crystallographic matching between the newly grown phase and the parental phase. Therefore, the promoted nucleation of a product, such as $\mathrm{MgB}_{2}$, results in faster dehydrogenation kinetic behavior.

According to the edge-to-edge matching model [63], the crystallographic matching is determined with small interplanar spacing mismatch $f_{d}$ of close-packed planes (below $6 \%$ ) and interatomic spacing misfit $f_{s}$ along with the matching close-packed directions (less than $10 \%$ ) between two phases. In addition, the matching directions have to lie in matching planes. The close-packed plane is commonly based on the structure factor $\left(F_{h k l}\right)$ and the interplanar spacing $d_{h k l}$. The large values of $F_{h k l}$ and $d_{h k l}$ result in the smaller area per atom in the plane ( $h k l)$, leading to the nearer planes being close-packed [72]. These values (i.e., $F_{h k l}$ and $d_{h k l}$ ) depend on the lattice parameters of the unit cell. In this study, $\mathrm{MgB}_{2}, \mathrm{AlTi}_{3}$, and $\mathrm{Al}_{2} \mathrm{O}_{3}$ are described in terms of the Miller-Bravais indices and crystal structures with different lattice parameters, leading to different close-packed planes observed on these phases. For $\mathrm{MgB}_{2}$, three possible close-packed planes are $\{10 \overline{1} 1\}\{10 \overline{1} 0\}$, and $\{0002\}$, while the possible close-packed planes for $\mathrm{AlTi}_{3}$ are $\{20 \overline{2} 1\},\{20 \overline{2} 2\}$, and $\{20 \overline{2} 0\}$, and the close-packed plane of $\mathrm{Al}_{2} \mathrm{O}_{3}$ is $\{11 \overline{2} 0\}$. Accordingly, there are a total of nine possible matching plane pairs between $\mathrm{MgB}_{2}$ and $\mathrm{AlTi}_{3}$ and three possible matching plane pairs between $\mathrm{MgB}_{2}$ and $\mathrm{Al}_{2} \mathrm{O}_{3}$. The calculation of interplanar spacing mismatch $\left(f_{d}\right)$ of these possible matching plane pairs between the $\mathrm{MgB}_{2}, \mathrm{AlTi}_{3}$, and $\mathrm{Al}_{2} \mathrm{O}_{3}$ are shown in Supplementary Materials ESI_Table S1. As seen there, two possible matching plane pairs for $\mathrm{MgB}_{2}$ and $\mathrm{AlTi}_{3}$ with a mismatch less than $6 \%$ are $\{10 \overline{1} 1\}_{\mathrm{MgB}_{2}} / /\{20 \overline{2} 1\}_{\mathrm{AlTi}_{3}}$ and $\{0002\}_{\mathrm{MgB}_{2}} / /\{20 \overline{2} 0\}_{\mathrm{AlTi}_{3}}$. In addition, the close-packed plane pair $\{10 \overline{10}\}_{\mathrm{MgB}_{2}} / /\{20 \overline{2} 0\}_{\mathrm{AlTi}_{3}}$ has a $d$-value mismatch of $6.3 \%$. This plane pair could also be considered a potential matching plane if the closepacked directions on these matching planes satisfy the interatomic spacing mismatch below $10 \%$ [63]. In addition, there are no matching planes between $\mathrm{MgB}_{2}$ and $\mathrm{Al}_{2} \mathrm{O}_{3}$ 
associated with the lattice mismatches of close-packed planes over $6 \%$ between these phases. However, the low lattice mismatch of close-packed planes is insufficient to predict orientation relationships between the two $\mathrm{MgB}_{2}$ and $\mathrm{AlTi}_{3}$ phases, particularly for a structure system as complex as the hexagonal one. Within this regard, the close-packed atom directions in two phases have to be matched with an interatomic spacing misfit of less than $10 \%$, and the matching directions must lie on the matching planes. $\mathrm{MgB}_{2}$ and $\mathrm{AlTi}_{3}$ are hexagonal close-packed structures (hcp) in which there are four possible closepacked directions: straight atom row $\langle 11 \overline{2} 0\rangle$ and zigzag atom rows $\langle 10 \overline{1} 0\rangle,\langle 11 \overline{2} 3\rangle$, and $\langle 0001\rangle$. These close-packed directions are also reported in literature [73-75], while $\mathrm{Al}_{2} \mathrm{O}_{3}$ has one close-packed direction $\langle 10 \overline{1} 0\rangle$ (straight row) [76]. As the result, the close-packed directions on the closed packed planes for $\mathrm{MgB}_{2}:\langle 11 \overline{2} 0\rangle,\langle 11 \overline{2} 3\rangle$, and $\langle 0001\rangle$ on $\{10 \overline{1} 1\}$; $\langle 11 \overline{2} 0\rangle,\langle 10 \overline{1} 0\rangle$, and $\langle 0001\rangle$ on $\{10 \overline{1} 0\}$; and $\langle 11 \overline{2} 0\rangle$ and $\langle 10 \overline{1} 0\rangle$ on $\{0002\}$. Similarly, the close-packed directions for $\mathrm{AlTi}_{3}$ can be found: $\langle 11 \overline{2} 0\rangle,\langle 11 \overline{2} 3\rangle$, and $\langle 0001\rangle$ on $\{20 \overline{2} 1\}$; $\langle 11 \overline{2} 0\rangle,\langle 10 \overline{1} 0\rangle$, and $\langle 11 \overline{2} 3\rangle$ on $\{20 \overline{2} 2\}$, and $\langle 11 \overline{2} 0\rangle,\langle 0001\rangle$, and $\langle 10 \overline{1} 0\rangle$ on $\{20 \overline{2} 0\}$. Following the rule of the edge-to-edge matching model [63], to maximize the matching of atoms across the interface, a straight atom row in one phase matches with straight atom rows in the other phase, and a zigzag row matches with zigzag rows. Considering $\mathrm{AlTi}_{3}$ as a parental phase, the interatomic spacing misfit of direction matching pairs $\left(f_{s}\right)$ was calculated, as shown in Supplementary Materials ESI-Table S2 and the mismatch with less than $10 \%$ belongs to the matching direction pair $\langle 11 \overline{2} 3\rangle_{\mathrm{MgB}_{2}} / /\langle 1101\rangle_{\mathrm{AlTi}_{3}}\left(f_{s}=0.73 \%\right)$. As concluded, there is one matching direction pair $\langle 11 \overline{2} 3\rangle_{\mathrm{MgB}_{2}} / /\langle 1101\rangle_{\mathrm{AlTi}_{3}}$ on one matching plane $\{10 \overline{1} 1\}_{\mathrm{MgB}_{2}} / /\{20 \overline{2} 1\}_{\mathrm{AlTi}_{3}}$. This implies that $\mathrm{AlTi}_{3}$ could act as heterogeneous nucleation sites for nucleating of $\mathrm{MgB}_{2}$. The calculation also points out that $\mathrm{Al}_{2} \mathrm{O}_{3}$ does not have a good crystallographic matching with $\mathrm{MgB}_{2}$. The large lattice mismatch between $\mathrm{MgB}_{2}$ and $\mathrm{Al}_{2} \mathrm{O}_{3}$ is also found in $[77,78]$. Therefore, it is not expected that the presence of $\mathrm{Al}_{2} \mathrm{O}_{3}$ in the composite improves the reaction kinetics of the Li-RHC system. In addition, during the measurement at high temperature (i.e., $400{ }^{\circ} \mathrm{C}$ ), $\mathrm{Mg}$ might have reacted with $\mathrm{Al}_{2} \mathrm{O}_{3}$ to form $\mathrm{MgO}$ and $\mathrm{Al}\left(3 \mathrm{Mg}+\mathrm{Al}_{2} \mathrm{O}_{3}=3 \mathrm{MgO}+2 \mathrm{Al}, \Delta \mathrm{G}_{400}{ }^{\circ} \mathrm{C}=-122.4 \mathrm{~kJ}\right)$ [79]. The formation of $\mathrm{MgO}$ confirmed by XRD, shown in Supplementary Materials ESI-Figure S3, can also negatively react to the hydrogen uptake-release kinetic behavior of the $\mathrm{Li}-\mathrm{RHC}$ system. The location of nanostructured additives such as $\mathrm{AlTi}_{3}$ at the grain boundaries is crucial for the nucleation of the phase that assured the reversibility of the system, i.e., $\mathrm{MgB}_{2}$. In this regard, the in situ formation of $\mathrm{AlTi}_{3}$ from the precursor $3 \mathrm{TiCl}_{3} \cdot \mathrm{AlCl}_{3}$ during ball milling leads to its better distribution at the grain boundaries. The addition of previously synthesized $\mathrm{AlTi}_{3}$ nanoparticles to Li-RHC might result in an inhomogeneous distribution of this species and, hence, the weaker performance of the system.

To evaluate the rate-limiting step of the first hydrogen absorption process, the gassolid models described in [70] were applied. Particular emphasis was placed on understanding whether the improved kinetic behavior of the Li-RHC material by the addition of $\mathrm{AlTi}_{3}$ nanoparticles is related to a change in the rate-limiting step. The fitting procedure is based on Sharp's and Jone's method [69,71], in which it is assumed that the most suitable reaction model provides a linear fitting with the highest correlation coefficient $R^{2}$ and a straight line through the origin with a slope close to 1 . In this investigation, different reaction kinetic equations (Supplementary Materials ESI-Table S3) [36] were applied to the experimental data of the hydrogenation for the $\mathrm{Li}-\mathrm{RHC}+\mathrm{AlTi}_{3}$ sample measured at $400{ }^{\circ} \mathrm{C}$ and 50 bar of hydrogen. Then, when a good fit of the experimental data concerning a specific kinetic equation can be achieved, the rate-limiting step of the kinetics can be determined. For the fitting, only the converted fraction $(\alpha)$ between 0.1 and 0.9 is considered. This procedure is applied to prevent the uncertainty associated with the acquisition of the initial and final points of the reactions. As an example of the fitting process, the hydrogenation behavior of the $\mathrm{Li}-\mathrm{RHC}+\mathrm{AlTi}_{3}$ is best described by the three-dimensional contracting volume reaction model $(\mathrm{CV}, n=3)$ with the highest correlation coefficient $\mathrm{R}^{2}$ of 0.997, the slope close to 1 , and the intercept equal to 0, amongst others, as shown in Figure 6. Comparison of this result with the data for the pristine $\mathrm{Li}-\mathrm{RHC}$ and $\mathrm{Li}-\mathrm{RHC}+3 \mathrm{TiCl}_{3} \cdot \mathrm{AlCl}_{3}$ 
samples given in [50] proves that the addition of $\mathrm{AlTi}_{3}$ nanoparticles has changed the reaction mechanism for the hydrogenation of the Li-RHC system from a one-dimensional interface-controlled reaction to a three-dimensional interface-controlled reaction.

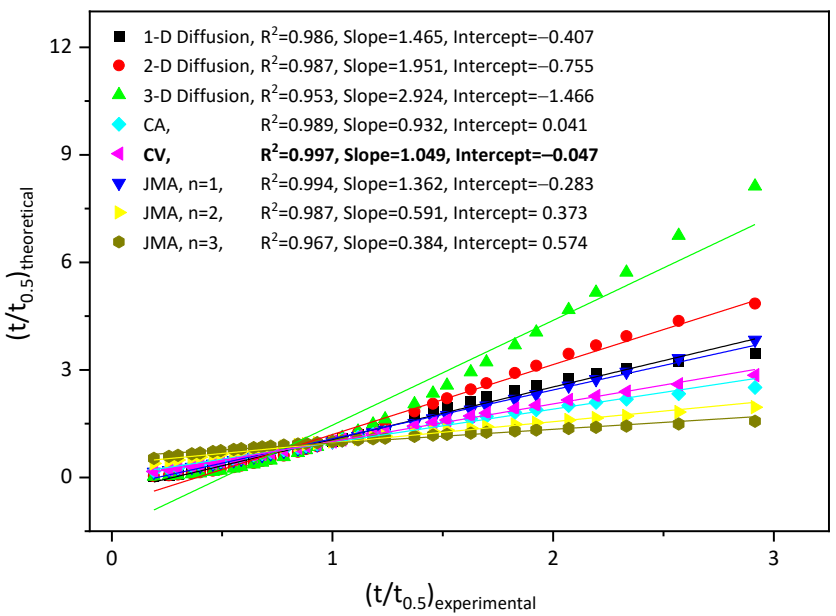

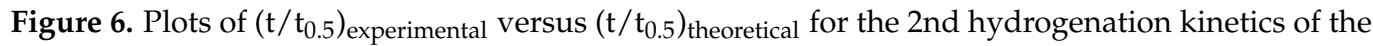
$\mathrm{Li}-\mathrm{RHC}+\mathrm{AlTi}_{3}$ sample at $400{ }^{\circ} \mathrm{C}$ and under 50 bar of $\mathrm{H}_{2}$.

The activation energy for the hydrogenation process was determined by fitting the kinetic curves with the selected reaction model. The 2 nd hydrogenation kinetic curves of the $\mathrm{Li}-\mathrm{RHC}+\mathrm{AlTi}_{3}$ in the range of temperature between $380{ }^{\circ} \mathrm{C}$ and $410{ }^{\circ} \mathrm{C}$ were fitted with the CV $(n=3)$ model. The fitting results and the calculated activation energy for the hydrogenation are presented in Figure 7. As seen in Figure 7a, the measured and the fitted data of the $\mathrm{Li}-\mathrm{RHC}+\mathrm{AlTi}_{3}$ sample show a good matching with correlation coefficients $\mathrm{R}^{2}$ close to 1. A kinetic rate constant $(k)$ is obtained from the fitting of each hydrogenation curve (Supplementary Materials ESI-Table S4) for each hydrogenation curve fitted. As seen in Figure $7 \mathrm{~b}$, the activation energy of the hydrogenation is about $123 \pm 3 \mathrm{~kJ} / \mathrm{mol} \mathrm{H}_{2}$. This value is significantly lower than that of the pristine $\mathrm{Li}-\mathrm{RHC}\left(E_{\mathrm{a}}=184 \pm 6 \mathrm{~kJ} / \mathrm{mol} \mathrm{H}_{2}\right)$, and similar to that of the $\mathrm{Li}-\mathrm{RHC}+3 \mathrm{TiCl}_{3} \cdot \mathrm{AlCl}_{3}$ sample $\left(E_{\mathrm{a}}=124 \pm 6 \mathrm{~kJ} / \mathrm{mol} \mathrm{H}_{2}\right)$ given in [50]. This result indicates that the presence of $\mathrm{AlTi}_{3}$ nanoparticles changed the rate-limiting step and reduced the activation energy of the hydrogenation process, leading to the faster kinetic properties of the $\mathrm{Li}-\mathrm{RHC}+\mathrm{AlTi}_{3}$ compared with the neat $\mathrm{Li}-\mathrm{RHC}$ system.

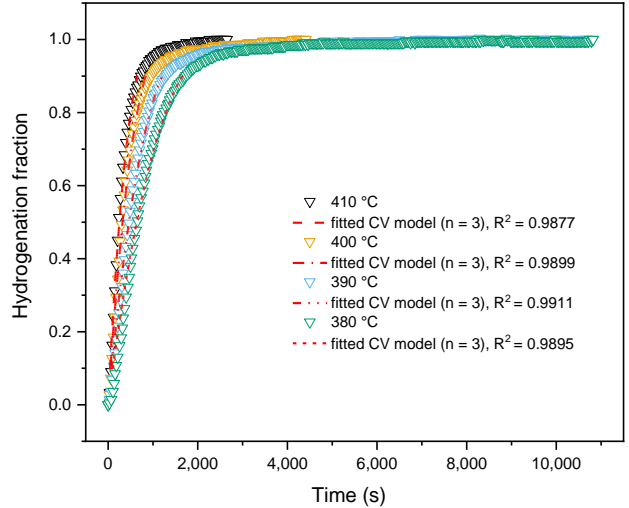

(a)

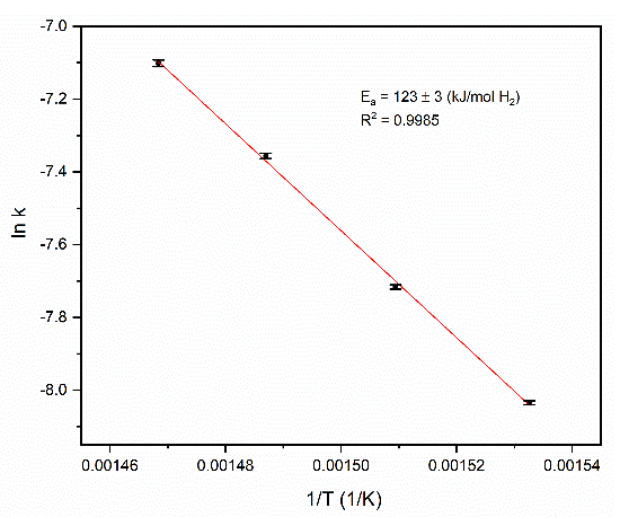

(b)

Figure 7. (a) The hydrogenation kinetic curves of the Li-RHC $+\mathrm{AlTi}_{3}$ sample at different temperatures fitted with $\mathrm{CV}(n=3)$ model; and (b) calculated hydrogenation activation energy of the $\mathrm{Li}-\mathrm{RHC}+\mathrm{AlTi}_{3}$ sample. 
Similar to the hydrogenation process, the activation energy for the dehydrogenation was also determined. Since the dehydrogenation behavior of the $\mathrm{Li}-\mathrm{RHC}+\mathrm{AlTi}_{3}$ material takes place in two consecutive steps, similar to the dehydrogenation of the Li-RHC and the $\mathrm{Li}-\mathrm{RHC}+3 \mathrm{TiCl}_{3} \cdot \mathrm{AlCl}_{3}$, thus the fitting procedure of this material is equivalent to the ones described for the pristine $\mathrm{Li}-\mathrm{RHC}$ and $\mathrm{Li}-\mathrm{RHC}+3 \mathrm{TiCl}_{3} \cdot \mathrm{AlCl}_{3}$ materials, in which the combination of two kinetic reaction models are used [50,68]. The dehydrogenation kinetic curves of the $\mathrm{Li}-\mathrm{RHC}+\mathrm{AlTi}_{3}$ sample measured in the range of $370{ }^{\circ} \mathrm{C}$ and $400{ }^{\circ} \mathrm{C}$ under three bar of hydrogen were then fitted. The results obtained from the fitting, as presented in Figure 8a, show a good agreement between the measured and fitted data with all correlation coefficients $\left(R^{2}\right)$ near 1 (Supplementary Materials ESI-Table S5). Figure $8 b$ shows the plot of $\ln (k)$ versus $1 / \mathrm{T}$ where the activation energy of the 1st and the 2 nd reaction step for the $\mathrm{Li}-\mathrm{RHC}+\mathrm{AlTi}_{3}$ sample are determined about $150 \pm 7 \mathrm{~kJ} / \mathrm{mol} \mathrm{H}_{2}$ and $270 \pm 5 \mathrm{~kJ} / \mathrm{mol} \mathrm{H}_{2}$, respectively. These values are lower by $\sim 20\left(\mathrm{~kJ} / \mathrm{mol} \mathrm{H}_{2}\right)$ compared with the values of the neat Li-RHC sample (e.g., the 1st reaction step: $172 \pm 19 \mathrm{~kJ} / \mathrm{mol} \mathrm{H}_{2}$ and the 2nd reaction step: $293 \pm 12 \mathrm{~kJ} / \mathrm{mol} \mathrm{H}_{2}$ ) [50]. However, compared with the sample plus $3 \mathrm{TiCl}_{3} \cdot \mathrm{AlCl}_{3}$ additive also given in [51], the activation energies for dehydrogenation of the Li-RHC + $\mathrm{AlTi}_{3}$ sample are slightly higher. These findings are in good accordance with the kinetic behavior reported above for the investigated materials [50].

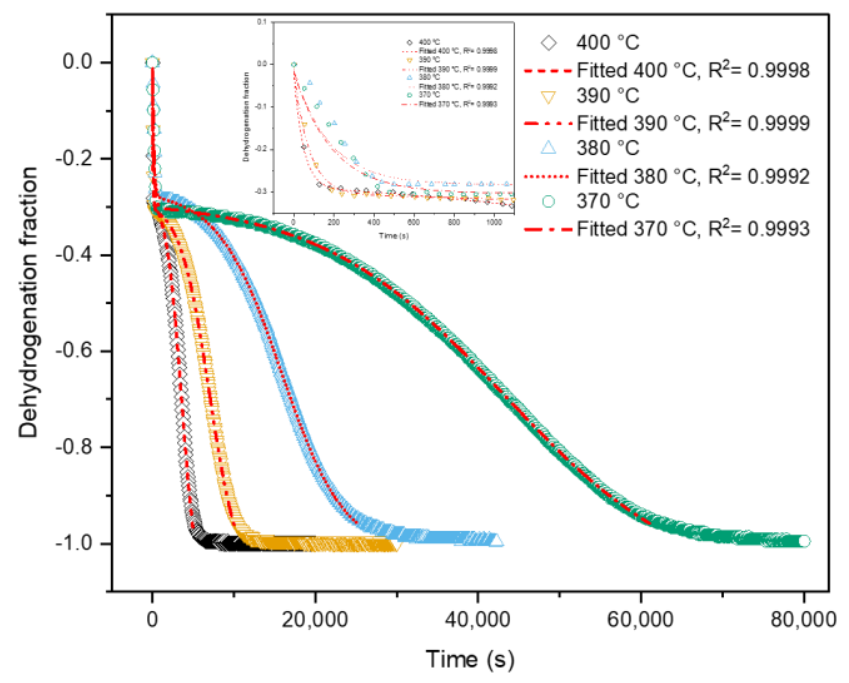

(a)

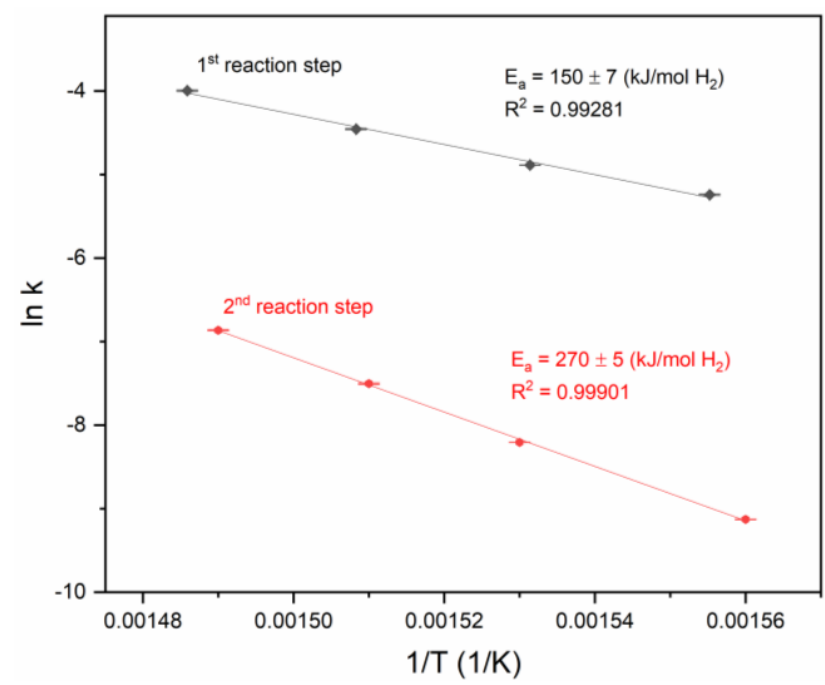

(b)

Figure 8. (a) The dehydrogenation kinetics and their fitted curves of $\mathrm{Li}-\mathrm{RHC}+\mathrm{AlTi}_{3}$ sample at different temperatures; and (b) dehydrogenation activation energy of the $\mathrm{Li}-\mathrm{RHC}+\mathrm{AlTi}_{3}$ sample.

Based on the results obtained in this work, the possibility of synthesizing nanometric $\mathrm{AlTi}_{3}$ particles and using those as an additive for the system $\mathrm{Li}-\mathrm{RHC}$ was investigated. $\mathrm{AlTi}_{3}$ was synthesized via $\mathrm{BM}$ of a stoichiometric mixture of $\mathrm{NaH}$ and $3 \mathrm{TiCl}_{3} \cdot \mathrm{AlCl}_{3}$. XRD and HR-TEM have verified the formation of hexagonal $\mathrm{AlTi}_{3}$ nanoparticles $(10 \mathrm{~nm})$. Apart from the existence of a hexagonal $\mathrm{AlTi}_{3}$ phase, nanoparticles of $\mathrm{Al}_{2} \mathrm{O}_{3}$ were also observed among the reaction products after the washing and drying procedures. The volumetric results show that upon cycling, the presence of $\mathrm{AlTi}_{3}$ nanoparticles enhances the hydrogenationdehydrogenation kinetics of the Li-RHC system significantly. However, in comparison with the $\mathrm{Li}-\mathrm{RHC}+3 \mathrm{TiCl}_{3} \cdot \mathrm{AlCl}_{3}$ material specified in [50], the hydrogenation-dehydrogenation kinetic behaviors of the Li-RHC $+\mathrm{AlTi}_{3}$ material are slightly slower. This behavior can be attributed to the lower number of nucleation sites (i.e., $\mathrm{AlTi}_{3}$ species compared with the reference system doped with $3 \mathrm{TiCl}_{3} \cdot \mathrm{AlCl}_{3}$ ) present in the added material. 


\section{Conclusions}

The results reported in this study show that the synthesis and the use of nanoparticles (i.e., $\mathrm{AlTi}_{3}$ nanoparticles) pave the way for a possible solution to improve the sorption kinetics of the RHC systems avoiding considerable hydrogen capacity loss (due to side reactions of additives with the hydride matrix). The synthesis performed in this work can be optimized by making the washing and drying processes in an inert atmosphere so that the formation of oxide compounds such as $\mathrm{Al}_{2} \mathrm{O}_{3}$ and $\mathrm{MgO}$ is minimized. Further investigations on possible synthetic pathways for producing nanostructured TM-based nanoparticle compounds are part of ongoing research. This approach can lead to an optimal tuning of the dynamic properties of hydride complex systems for efficient hydrogen storage.

Supplementary Materials: The following are available online at https://www.mdpi.com/article/ 10.3390/en14237853/s1, Figure S1: Gibbs minimization equilibrium calculations for the interaction between $\mathrm{AlTi}_{3}$ and water, Figure S2: TEM diffraction of the mixture $\mathrm{NaH}+3 \mathrm{TiCl}_{3} \cdot \mathrm{AlCl}_{3}$ after washing and drying and possible phases, Figure S3: XRD diffractograms of Li-RHC + $\mathrm{AlTi}_{3}$ sample after 4 cycles, Table S1: Interplanar spacing mismatch (\%) of possible close-packed plane pairs between $\mathrm{MgB}_{2}, \mathrm{AlTi}_{3}$, and $\mathrm{Al}_{2} \mathrm{O}_{3}$, Table S2: Interatomic spacing misfit (\%) of possible matching directions between $\mathrm{MgB}_{2}, \mathrm{AlTi}_{3}$, and $\mathrm{Al}_{2} \mathrm{O}_{3}$, Table S3: Gas-solid reaction models and their integral expressions, Table S4: Fitting parameters of the hydrogenation kinetic curves, Table S5: Fitting parameters of the dehydrogenation kinetic curves.

Author Contributions: Conceptualization, T.-T.L. and C.P.; methodology, T.-T.L.; investigation, T.-T.L.; resources, T.-T.L., D.M.D., J.P. and M.V.C.R.; writing—original draft preparation, T.-T.L.; writing - review and editing, T.-T.L., C.P., M.D., J.P. and T.K.; supervision, C.P., M.D. and T.K.; funding acquisition, T.K. All authors have read and agreed to the published version of the manuscript.

Funding: This research was funded by DFG (Deutsche Forschungsgemeinschaft), grant number PU 131/16-1.

Data Availability Statement: Data available on request due to restrictions e.g., privacy or ethical. The data presented in this study are available on request from the corresponding author. The data are not publicly available due to the regulations of data protection of the responsible institute.

Acknowledgments: The authors acknowledge Metal Physics Group from HZG (currently Hereon) for the use of the microscope facilities.

Conflicts of Interest: The authors declare no conflict of interest. The funders had no role in the design of the study; in the collection, analyses, or interpretation of data; in the writing of the manuscript, or in the decision to publish the results.

\section{References}

1. Schlapbach, L.; Züttel, A. Hydrogen-storage materials for mobile applications. Nature 2001, 414, 353. [CrossRef] [PubMed]

2. Züttel, A.; Borgschulte, A.; Schlapbach, L. Hydrogen as a Future Energy Carrier. Philos. Trans. R. Soc. A Math. Phys. Eng. Sci. 2007, 368, 3329-3342. [CrossRef] [PubMed]

3. Global Warming of $1.5{ }^{\circ} \mathrm{C}$. Summary for Policymakers. Available online: https://www.ipcc.ch/sr15/ (accessed on 30 October 2021).

4. Hassanpouryouzband, A.; Joonaki, E.; Edlmann, K.; Haszeldine, R.S. Offshore Geological Storage of Hydrogen: Is This Our Best Option to Achieve Net-Zero? ACS Energy Lett. 2021, 6, 2181-2186. [CrossRef]

5. Klebanoff, L. Hydrogen Storage Technology: Materials and Applications; CRC Press: Boca Raton, FL, USA, 2016.

6. Hirscher, M. Handbook of Hydrogen Storage: New Material for Future Energy Storage; WILEY-VCH Verlag GmbH \& Co. KGaA: Weinheim, Germany, 2010.

7. Felderhoff, M.; Weidenthaler, C.; von Helmolt, R.; Eberle, U. Hydrogen storage: The remaining scientific and technological challenges. Phys. Chem. Chem. Phys. 2007, 9, 2643-2653. [CrossRef] [PubMed]

8. Züttel, A. Materials for Hydrogen Storage. Mater. Today 2003, 6, 24-33. [CrossRef]

9. Broom, D.P. Hydrogen Storage Materials: The Characterisation of Their Storage Properties. In Green Energy and Technology; Springer: London, UK, 2011.

10. Broom, D.P.; Webb, C.J.; Fanourgakis, G.S.; Froudakis, G.E.; Trikalitis, P.N.; Hirscher, M. Concepts for improving hydrogen storage in nanoporous materials. Int. J. Hydrogen Energy 2019, 44, 7768-7779. [CrossRef] 
11. Broom, D.P.; Webb, C.J.; Hurst, K.E.; Parilla, P.A.; Gennett, T.; Brown, C.M.; Zacharia, R.; Tylianakis, E.; Klontzas, E.; Froudakis, G.E.; et al. Outlook and challenges for hydrogen storage in nanoporous materials. Appl. Phys. A 2016, $122,151$. [CrossRef]

12. 2025 DOE Technical Targets for Onboard Hydrogen Storage for Light-Duty Vehicles. Available online: https:/ / www.energy.gov / (accessed on 30 October 2021).

13. Lee, H.; Lee, J.-w.; Kim, D.Y.; Park, J.; Seo, Y.-T.; Zeng, H.; Moudrakovski, I.L.; Ratcliffe, C.I.; Ripmeester, J.A. Tuning clathrate hydrates for hydrogen storage. Nature 2005, 434, 743-746. [CrossRef] [PubMed]

14. Florusse Louw, J.; Peters Cor, J.; Schoonman, J.; Hester Keith, C.; Koh Carolyn, A.; Dec Steven, F.; Marsh Kenneth, N.; Sloan, E.D. Stable Low-Pressure Hydrogen Clusters Stored in a Binary Clathrate Hydrate. Science 2004, 306, 469-471. [CrossRef]

15. Jepsen, L.H.; Ley, M.B.; Lee, Y.-S.; Cho, Y.W.; Dornheim, M.; Jensen, J.O.; Filinchuk, Y.; Jørgensen, J.E.; Besenbacher, F.; Jensen, T.R. Boron-nitrogen based hydrides and reactive composites for hydrogen storage. Mater. Today 2014, 17, 129-135. [CrossRef]

16. Ley, M.B.; Jepsen, L.H.; Lee, Y.-S.; Cho, Y.W.; Bellosta von Colbe, J.M.; Dornheim, M.; Rokni, M.; Jensen, J.O.; Sloth, M.; Filinchuk, Y.; et al. Complex hydrides for hydrogen storage-New perspectives. Mater. Today 2014, 17, 122-128. [CrossRef]

17. Buchner, H.; Schmidt.-Ihn, E.; Lang, U. Stationäre Hydridspeicher als Ausgleichsspeicher elektrischer Spitzenenergien. In Kommission der Europäischen Gemeinschaften; European Commission: Luxembourg, 1981.

18. Metallurgy, G.P. GKN Powder Metallurgy. Available online: https://www.gknpm.com/en/innovation/hydrogen-technology/ hy2green/ (accessed on 30 October 2021).

19. Psoma, A.; Sattler, G. Fuel cell systems for submarines: From the first idea to serial production. J. Power Sources 2002, 106, 381-383. [CrossRef]

20. Mauron, P.; Buchter, F.; Friedrichs, O.; Remhof, A.; Bielmann, M.; Zwicky, C.N.; Zuttel, A. Stability and reversibility of LiBH 4 . J. Phys. Chem. B 2008, 112, 906-910. [CrossRef]

21. Orimo, S.; Nakamori, Y.; Kitahara, G.; Miwa, K.; Ohba, N.; Towata, S.; Züttel, A. Dehydriding and rehydriding reactions of LiBH 4 . J. Alloys Compd. 2005, 404-406, 427-430. [CrossRef]

22. Orimo, S.-I.; Nakamori, Y.; Eliseo, J.R.; Züttel, A.; Jensen, C.M. Complex Hydrides for Hydrogen Storage. Chem. Rev. 2007, 107, 4111-4132. [CrossRef] [PubMed]

23. Orimo, S.-I.; Nakamori, Y.; Ohba, N.; Miwa, K.; Aoki, M.; Towata, S.-I.; Züttel, A. Experimental studies on intermediate compound of $\mathrm{LiBH}_{4}$. Appl. Phys. Lett. 2006, 89, 021920. [CrossRef]

24. Puszkiel, J.; Garroni, S.; Milanese, C.; Gennari, F.; Klassen, T.; Dornheim, M.; Pistidda, C. Tetrahydroborates: Development and Potential as Hydrogen Storage Medium. Inorganics 2017, 5, 74. [CrossRef]

25. Züttel, A.; Rentsch, S.; Fischer, P.; Wenger, P.; Sudan, P.; Mauron, P.; Emmenegger, C. Hydrogen storage properties of LiBH4. J. Alloys Compd. 2003, 356-357, 515-520. [CrossRef]

26. Züttel, A.; Wenger, P.; Rentsch, S.; Sudan, P.; Mauron, P.; Emmenegger, C. $\mathrm{LiBH}_{4}$ a new hydrogen storage material. J. Power Sources 2003, 118, 1-7. [CrossRef]

27. Milanese, C.; Jensen, T.R.; Hauback, B.C.; Pistidda, C.; Dornheim, M.; Yang, H.; Lombardo, L.; Zuettel, A.; Filinchuk, Y.; Ngene, P.; et al. Complex hydrides for energy storage. Int. J. Hydrogen Energy 2019, 44, 7860-7874. [CrossRef]

28. Reilly, J.J.; Wiswall, R.H. Reaction of hydrogen with alloys of magnesium and copper. Inorg. Chem. 1967, 6, 2220-2223. [CrossRef]

29. Chen, P.; Xiong, Z.; Luo, J.; Lin, J.; Tan, K.L. Interaction of hydrogen with metal nitrides and imides. Nature 2002, 420, 302. [CrossRef]

30. Barkhordarian, G.; Klassen, T.; Dornheim, M.; Bormann, R. Unexpected kinetic effect of $\mathrm{MgB}_{2}$ in reactive hydride composites containing complex borohydrides. J. Alloys Compd. 2007, 440, L18-L21. [CrossRef]

31. Vajo, J.J.; Skeith, S.L. Reversible Storage of Hydrogen in Destabilized $\mathrm{LiBH}_{4}$. Phys. Chem. B Lett. 2005, 109, 3719-3722. [CrossRef] [PubMed]

32. Garroni, S.; Pistidda, C.; Brunelli, M.; Vaughan, G.B.M.; Suriñach, S.; Baró, M.D. Hydrogen desorption mechanism of $2 \mathrm{NaBH}_{4}+\mathrm{MgH}_{2}$ composite prepared by high-energy ball milling. Scr. Mater. 2009, 60, 1129-1132. [CrossRef]

33. Czujko, T.; Varin, R.A.; Wronski, Z.; Zaranski, Z.; Durejko, T. Synthesis and hydrogen desorption properties of nanocomposite magnesium hydride with sodium borohydride $\left(\mathrm{MgH}_{2}+\mathrm{NaBH}_{4}\right)$. J. Alloys Compd. 2007, 427, 291-299. [CrossRef]

34. Xiong, Z.; Hu, J.; Wu, G.; Chen, P.; Luo, W.; Gross, K.; Wang, J. Thermodynamic and kinetic investigations of the hydrogen storage in the Li-Mg-N-H system. J. Alloys Compd. 2005, 398, 235-239. [CrossRef]

35. Nakamori, Y.; Kitahara, G.; Orimo, S. Synthesis and dehydriding studies of Mg-N-H systems. J. Power Sources 2004, 138, 309-312. [CrossRef]

36. Gizer, G.; Puszkiel, J.; Cao, H.; Pistidda, C.; Le, T.T.; Dornheim, M.; Klassen, T. Tuning the reaction mechanism and hydrogenation/dehydrogenation properties of $6 \mathrm{Mg}\left(\mathrm{NH}_{2}\right)_{2}-9 \mathrm{LiH}$ system by adding $\mathrm{LiBH}_{4}$. Int. J. Hydrogen Energy 2019, 44, 11920-11929. [CrossRef]

37. Bérubé, V.; Radtke, G.; Dresselhaus, M.; Chen, G. Size effects on the hydrogen storage properties of nanostructured metal hydrides: A review. Int. J. Energy Res. 2007, 31, 637-663. [CrossRef]

38. Berlouis, L.E.A.; Cabrera, E.; Hall-Barientos, E.; Hall, P.J.; Dodd, S.; Morris, S.; Imam, M.A. A thermal analysis investigation of the hydriding properties of nanocrystalline $\mathrm{Mg}-\mathrm{Ni}$ based alloys prepared by high energy ball milling. J. Alloys Compd. 2000, 305, 82-89. [CrossRef] 
39. Gertsman, V.Y.; Birringer, R. On the room-temperature grain growth in nanocrystalline copper. Scr. Metall. Mater. 1994, 30, 577-581. [CrossRef]

40. Suzuki, Y.; Haraki, T.; Uchida, H. Effect of LaNi5H6 hydride particles size on desorption kinetics. J. Alloys Compd. 2002, 330-332, 488-491. [CrossRef]

41. Vigeholm, B.; Kjøller, J.; Larsen, B.; Schrøder Pedersen, A. Hydrogen sorption performance of pure magnesium during continued cycling. Int. J. Hydrogen Energy 1983, 8, 809-817. [CrossRef]

42. Vega, L.E.R.; Leiva, D.R.; Leal Neto, R.M.; Silva, W.B.; Silva, R.A.; Ishikawa, T.T.; Kiminami, C.S.; Botta, W.J. Mechanical activation of TiFe for hydrogen storage by cold rolling under inert atmosphere. Int. J. Hydrogen Energy 2018, 43, 2913-2918. [CrossRef]

43. Strozi, R.B.; Ivanisenko, J.; Koudriachova, N.; Huot, J. Effect of HPT on the First Hydrogenation of LaNi5 Metal Hydride. Energies 2021, 14, 6710. [CrossRef]

44. Huot, J. Enhancing Hydrogen Storage Properties of Metal Hybrides Enhancement by Mechanical Deformations. In Briefs in Applied Sciences and Technology; Springer: Cham, Switzerland, 2016.

45. Bösenberg, U.; Kim, J.W.; Gosslar, D.; Eigen, N.; Jensen, T.R.; von Colbe, J.M.B.; Zhou, Y.; Dahms, M.; Kim, D.H.; Günther, R. Role of additives in LiBH4-MgH2 reactive hydride composites for sorption kinetics. Acta Mater. 2010, 58, 3381-3389. [CrossRef]

46. Bosenberg, U.; Vainio, U.; Pranzas, P.K.; von Colbe, J.M.; Goerigk, G.; Welter, E.; Dornheim, M.; Schreyer, A.; Bormann, R. On the chemical state and distribution of $\mathrm{Zr}$ - and V-based additives in reactive hydride composites. Nanotechnology 2009, $20,204003$. [CrossRef] [PubMed]

47. Deprez, E.; Justo, A.; Rojas, T.C.; López-Cartés, C.; Bonatto Minella, C.; Bösenberg, U.; Dornheim, M.; Bormann, R.; Fernández, A. Microstructural study of the $\mathrm{LiBH}_{4}-\mathrm{MgH}_{2}$ reactive hydride composite with and without Ti-isopropoxide additive. Acta Mater. 2010, 58, 5683-5694. [CrossRef]

48. Fan, M.; Sun, L.; Zhang, Y.; Xu, F.; Zhang, J.; Chu, H. The catalytic effect of additive $\mathrm{Nb}_{2} \mathrm{O}_{5}$ on the reversible hydrogen storage performances of $\mathrm{LiBH}_{4}-\mathrm{MgH}_{2}$ composite. Int. J. Hydrogen Energy 2008, 33, 74-80. [CrossRef]

49. Gizer, G.; Puszkiel, J.; Riglos, M.V.C.; Pistidda, C.; Ramallo-López, J.M.; Mizrahi, M.; Santoru, A.; Gemming, T.; Tseng, J.-C.; Klassen, T.; et al. Improved kinetic behaviour of $\mathrm{Mg}\left(\mathrm{NH}_{2}\right)_{2}-2 \mathrm{LiH}$ doped with nanostructured K-modified-Lix $\mathrm{Ti}_{\mathrm{y}} \mathrm{O}_{z}$ for hydrogen storage. Sci. Rep. 2020, 10, 8. [CrossRef] [PubMed]

50. Le, T.-T.; Pistidda, C.; Puszkiel, J.; Castro Riglos, M.V.; Karimi, F.; Skibsted, J.; GharibDoust, S.P.; Richter, B.; Emmler, T.; Milanese, C.; et al. Design of a Nanometric AlTi Additive for $\mathrm{MgB}_{2}$-Based Reactive Hydride Composites with Superior Kinetic Properties. J. Phys. Chem. C 2018, 122, 7642-7655. [CrossRef]

51. Liu, B.H.; Zhang, B.J.; Jiang, Y. Hydrogen storage performance of $\mathrm{LiBH}_{4}+1 / 2 \mathrm{MgH}_{2}$ composites improved by Ce-based additives. Int. J. Hydrogen Energy 2011, 36, 5418-5424. [CrossRef]

52. Santoru, A.; Garroni, S.; Pistidda, C.; Milanese, C.; Girella, A.; Marini, A.; Masolo, E.; Valentoni, A.; Bergemann, N.; Le, T.T.; et al. A new potassium-based intermediate and its role in the desorption properties of the $\mathrm{K}-\mathrm{Mg}-\mathrm{N}-\mathrm{H}$ system. Phys. Chem. Chem. Phys. 2016, 18, 3910-3920. [CrossRef] [PubMed]

53. Sridechprasat, P.; Suttisawat, Y.; Rangsunvigit, P.; Kitiyanan, B.; Kulprathipanja, S. Catalyzed $\mathrm{LiBH}_{4}$ and $\mathrm{MgH}_{2} \mathrm{mixture} \mathrm{for}$ hydrogen storage. Int. J. Hydrogen Energy 2011, 36, 1200-1205. [CrossRef]

54. Wang, P.; Ma, L.; Fang, Z.; Kang, X.; Wang, P. Improved hydrogen storage property of Li-Mg-B-H system by milling with titanium trifluoride. Energy Environ. Sci. 2009, 2, 120-123.

55. Bonatto Minella, C.; Garroni, S.; Pistidda, C.; Baró, M.D.; Gutfleisch, O.; Klassen, T.; Dornheim, M. Sorption properties and reversibility of $\mathrm{Ti}(\mathrm{IV})$ and $\mathrm{Nb}(\mathrm{V})$-fluoride doped-Ca $\left(\mathrm{BH}_{4}\right)_{2}-\mathrm{MgH}_{2}$ system. J. Alloys Compd. 2015, 622, 989-994. [CrossRef]

56. Karimi, F.; Pranzas, P.K.; Pistidda, C.; Puszkiel, J.A.; Milanese, C.; Vainio, U.; Paskevicius, M.; Emmler, T.; Santoru, A.; Utke, R.; et al. Structural and kinetic investigation of the hydride composite $\mathrm{Ca}\left(\mathrm{BH}_{4}\right)_{2}+\mathrm{MgH}_{2}$ system doped with $\mathrm{NbF}$ for solid-state hydrogen storage. Phys. Chem. Chem. Phys. 2015, 17, 27328-27342. [CrossRef] [PubMed]

57. Bonatto Minella, C.; Pellicer, E.; Rossinyol, E.; Karimi, F.; Pistidda, C.; Garroni, S.; Milanese, C.; Nolis, P.; Baro, M.D.; Gutfleisch, O.; et al. Chemical State, Distribution, and Role of Ti- and Nb-Based Additives on the Ca(BH$)_{2}$ System. J. Phys. Chem. C 2013, 117, 4394-4403. [CrossRef]

58. Xian, K.; Gao, M.; Li, Z.; Gu, J.; Shen, Y.; Wang, S.; Yao, Z.; Liu, Y.; Pan, H. Superior Kinetic and Cyclic Performance of a 2D Titanium Carbide Incorporated $2 \mathrm{LiH}+\mathrm{MgB}_{2}$ Composite toward Highly Reversible Hydrogen Storage. ACS Appl. Energy Mater. 2019, 2, 4853-4864. [CrossRef]

59. Le, T.T.; Pistidda, C.; Abetz, C.; Georgopanos, P.; Garroni, S.; Capurso, G.; Milanese, C.; Puszkiel, J.; Dornheim, M.; Abetz, V.; et al. Enhanced Stability of Li-RHC Embedded in an Adaptive TPX ${ }^{\mathrm{TM}}$ Polymer Scaffold. Materials 2020, 13, 991. [CrossRef] [PubMed]

60. Karimi, F.; Pranzas, P.K.; Puszkiel, J.A.; Castro Riglos, M.V.; Milanese, C.; Vainio, U.; Pistidda, C.; Gizer, G.; Klassen, T.; Schreyer, A.; et al. A comprehensive study on lithium-based reactive hydride composite (Li-RHC) as a reversible solid-state hydrogen storage system toward potential mobile applications. RSC Adv. 2021, 11, 23122-23135. [CrossRef]

61. Karimi, F.; Börries, S.; Pranzas, P.K.; Metz, O.; Hoell, A.; Gizer, G.; Puszkiel, J.A.; Riglos, M.V.C.; Pistidda, C.; Dornheim, M.; et al. Characterization of $\mathrm{LiBH}_{4}-\mathrm{MgH}_{2}$ Reactive Hydride Composite System with Scattering and Imaging Methods Using Neutron and Synchrotron Radiation. Adv. Eng. Mater. 2021, 23, 2100294. [CrossRef]

62. Karimi, F.; Riglos, M.V.C.; Santoru, A.; Hoell, A.; Raghuwanshi, V.S.; Milanese, C.; Bergemann, N.; Pistidda, C.; Nolis, P.; Baro, M.D.; et al. In Situ Formation of TiB2 Nanoparticles for Enhanced Dehydrogenation/Hydrogenation Reaction Kinetics 
of $\mathrm{LiBH}_{4}-\mathrm{MgH}_{2}$ as a Reversible Solid-State Hydrogen Storage Composite System. J. Phys. Chem. C 2018, 122, 11671-11681. [CrossRef]

63. Zhang, M.X.; Kelly, P.M. Edge-to-edge matching model for predicting orientation relationships and habit planes-the improvements. Scr. Mater. 2005, 52, 963-968. [CrossRef]

64. Moon, K.I.; Lee, K.S. A study of the microstructure of nanocrystalline Al-Ti alloys synthesized by ball milling in a hydrogen atmosphere and hot extrusion. J. Alloys Compd. 1999, 291, 312-321. [CrossRef]

65. HSC Chemistry. Available online: http://www.hsc-chemistry.net/index.html (accessed on 30 October 2021).

66. Kattner, U.R.; Lin, J.C.; Chang, Y.A. Thermodynamic Assessment and Calculation of the Ti-Al System. Metall. Trans. A 1992, 23, 2081-2090. [CrossRef]

67. Bösenberg, U.; Doppiu, S.; Mosegaard, L.; Barkhordarian, G.; Eigen, N.; Borgschulte, A.; Jensen, T.R.; Cerenius, Y.; Gutfleisch, O.; Klassen, T.; et al. Hydrogen sorption properties of $\mathrm{MgH}_{2}-\mathrm{LiBH}_{4}$ composites. Acta Mater. 2007, 55, 3951-3958. [CrossRef]

68. Puszkiel, J.A.; Castro Riglos, M.V.; Ramallo-Lopez, J.M.; Mizrahi, M.; Karimi, F.; Santoru, A.; Hoell, A.; Gennari, F.C.; Larochette, P.A.; Pistidda, C.; et al. A novel catalytic route for hydrogenation-dehydrogenation of $2 \mathrm{LiH}^{2} \mathrm{MgB}_{2}$ via in situ formed core-shell $\mathrm{Li}_{\mathrm{x}} \mathrm{TiO}_{2}$ nanoparticles. J. Mater. Chem. A 2017, 5, 12922-12933. [CrossRef]

69. Jones, L.F.; Dollimore, D.; Nicklin, T. Comparison of experimental kinetic decomposition data with master data using a linear plot method. Thermochim. Acta 1975, 13, 240-245. [CrossRef]

70. Khawam, A.; Flanagan, D.R. Solid-State Kinetic Models: Basics and Mathematical Fundamentals. J. Phys. Chem. B 2006, 110, 17315-17328. [CrossRef] [PubMed]

71. Sharp, J.H.; Brindley, G.W.; Achar, B.N.N. Numerical Data for Some Commonly Used Solid State Reaction Equations. J. Am. Ceram. Soc. 1966, 49, 379-382. [CrossRef]

72. Kelly, P.M.; Ren, H.P.; Qiu, D.; Zhang, M.X. Identifying close-packed planes in complex crystal structures. Acta Mater. 2010, 58, 3091-3095. [CrossRef]

73. Yang, J.; Wang, J.L.; Wu, Y.M.; Wang, L.M.; Zhang, H.J. Extended application of edge-to-edge matching model to HCP/HCP $\left(\alpha-\mathrm{Mg} / \mathrm{MgZn}_{2}\right)$ system in magnesium alloys. Mater. Sci. Eng. A 2007, 460-461, 296-300. [CrossRef]

74. Zhang, M.X.; Kelly, P.M. Edge-to-edge matching and its applications: Part I. Application to the simple HCP/BCC system. Acta Mater. 2005, 53, 1073-1084. [CrossRef]

75. Zhang, M.X.; Kelly, P.M.; Easton, M.A.; Taylor, J.A. Crystallographic study of grain refinement in aluminum alloys using the edge-to-edge matching model. Acta Mater. 2005, 53, 1427-1438. [CrossRef]

76. Lee, W.E.; Lagerlof, K.P.D. Structural and electron diffraction data for sapphire $\left(\alpha-\mathrm{Al}_{2} \mathrm{O}_{3}\right)$. J. Electron. Microsc. Tech. 1985, 2, 247-258. [CrossRef]

77. Won Kyung, S.; Sangjun, O.; Won Nam, K. Perfect Domain-Lattice Matching between $\mathrm{MgB}_{2}$ and $\mathrm{Al}_{2} \mathrm{O}_{3}: \mathrm{Single}^{-\mathrm{Crystal}} \mathrm{MgB}_{2}$ Thin Films Grown on Sapphire. Jpn. J. Appl. Phys. 2012, 51, 083101.

78. Tian, W.; Pan, X.Q.; Bu, S.D.; Kim, D.M.; Choi, J.H.; Patnaik, S.; Eom, C.B. Interfacial structure of epitaxial MgB $\mathrm{M}_{2}$ thin films grown on (0001) sapphire. Appl. Phys. Lett. 2002, 81, 685-687. [CrossRef]

79. Hallstedt, B.; Liu, Z.-K.; Ågren, J. Reactions in $\mathrm{Al}_{2} \mathrm{O}_{3}-\mathrm{Mg}$ metal matrix composites during prolonged heat treatment at 400,550 and $600{ }^{\circ}$ C. Mater. Sci. Eng. A 1993, 169, 149-157. [CrossRef] 